\title{
A NEW MEASURE OF COLLEGE QUALITY TO STUDY THE EFFECTS OF COLLEGE SECTOR AND PEERS ON DEGREE ATTAINMENT
}

\author{
Jonathan Smith \\ Kevin Stange \\ Working Paper 21605 \\ http://www.nber.org/papers/w21605
NATIONAL BUREAU OF ECONOMIC RESEARCH
1050 Massachusetts Avenue
Cambridge, MA 02138
October 2015

The results of the paper reflect the views of the authors and not of their respective institutions, nor of the National Bureau of Economic Research.

NBER working papers are circulated for discussion and comment purposes. They have not been peerreviewed or been subject to the review by the NBER Board of Directors that accompanies official NBER publications.

(C) 2015 by Jonathan Smith and Kevin Stange. All rights reserved. Short sections of text, not to exceed two paragraphs, may be quoted without explicit permission provided that full credit, including $\odot$ notice, is given to the source. 
A New Measure of College Quality to Study the Effects of College Sector and Peers on Degree Attainment

Jonathan Smith and Kevin Stange

NBER Working Paper No. 21605

October 2015

JEL No. I21,I23

\begin{abstract}
$\underline{\text { ABSTRACT }}$
Students starting at a two-year college are much less likely to graduate with a college degree than similar students who start at a four-year college but the sources of this attainment gap are largely unexplained. In this paper we simultaneously investigate the attainment consequences of sector choice and peer quality among over 3 million recent high school graduates. This analysis is enabled by data on all PSAT test-takers between 2004 and 2006 from which we develop a novel measure of peer ability for most two-year and four-year colleges in the United States- the average PSAT of enrolled students. We document substantial variation in average peer quality at two-year colleges across and within states and non-trivial overlap across sectors, neither of which has previously been documented. We find that half the gap in bachelor's attainment rates between students who start at two-year versus[fouryear institutions is explained by differences in peers, leaving room for structural barriers to transferring between institutions to also play an important role. Also, having better peers is associated with higher attainment in both sectors, though its effects are quite a bit larger in the four-year sector. Thus, the allocation of students between and within sectors, some of which is driven by state policy decisions, has important consequences for the educational attainment of the nation's workforce.
\end{abstract}

Jonathan Smith

College Board

1919 M Street NW

Suite 300

Washington, DC 20036

jsmith@collegeboard.org

Kevin Stange

Gerald R. Ford School of Public Policy

University of Michigan

5236 Weill Hall

735 South State Street

Ann Arbor, MI 48109

and NBER

kstange@umich.edu 


\section{Introduction}

Many students who aspire to earn a bachelor's degree and with the academic credentials to start at a four-year college instead begin at a two-year or community college (Bowen, Chingos, McPherson, 2009; Smith, Pender, and Howell, 2013). Starting at a community college is appealing because it is an inexpensive way to earn credits and prepare for upper division coursework. For example, for the 2014-15 academic year, the average published tuition and fees for a student attending an instate public two-year college is $\$ 3,350$, an instate public four-year is $\$ 9,140$, and a private four-year is $\$ 31,230$ (College Board, 2014). ${ }^{1}$ On the other hand, research suggests that observably similar students who start at two-year colleges are much less likely to attain a bachelor's degree (Rouse, 1995; Doyle. 1999; Long and Kurlaender. 2009; Reynolds, 2012; Goodman, Hurwitz, and Smith, 2014). ${ }^{2}$ In fact, Bound, Lovenheim, and Turner (2010) find that shifts from the 4-year to 2-year colleges can explain a large share of the decline in college completion rates between 1972 and 1992. A limitation of this research is that it doesn’t inform why students starting at two-year schools perform worse than those that start in four-year colleges. Two-year colleges differ from four-year colleges in many ways that may influence outcomes, including financial resources, peer students, a requirement to transfer, and student intentions and preparation. Increasing college resources, altering peer exposure, streamlining transfer processes, and improving student preparation are quite distinct policy responses so distinguishing between these explanations is important.

\footnotetext{
${ }^{1}$ Net tuitions are substantially lower but the gaps between sectors remain on average.

${ }^{2}$ Using administrative data from the state of Texas, Miller (2007) and Andrews, Li, and Lovenheim (2012) also find that sector has substantial impacts on earnings as well.
} 
This paper contributes to this literature in two ways. First, it is arguably the first to measure the influence of college quality in the community college sector, ${ }^{3}$ made possible by the construction of a new measure of average peer ability that is comparable within and across sectors. ${ }^{4}$ Previous studies have used instructional spending to measure community college quality (Stange, 2012), yet this is a weak measure of institution quality and doesn't capture the role of peers, an important input into the education production function. The second contribution is to quantify the role of peer ability in explaining the BA attainment rate difference between traditional college students across the two- and four-year sectors. Our measure of peer ability uses a unique dataset on nearly 3 million Preliminary SAT/ National Merit Scholarship Qualifying Test ${ }^{\circledR}$ (PSAT) takers in 2004-2006 merged to enrollment and completion data from the National Student Clearinghouse (NSC). The PSAT has strong coverage across the country even for those enrolling in two-year colleges, allowing us to measure peer ability in a way that is comparable across sectors and similar to that of the average SAT or ACT, which is a common measure of college quality used to study four-year colleges. We document substantial variation in average peer ability at two-year colleges across and within states and non-trivial overlap between sectors, neither of which has previously been documented. Kurlaender, Carrell, and Jackson (2014) also document considerable variation in outcomes among the 108 community colleges in California, even after accounting for student selection. They find that accounting for average peer characteristics substantially reduces, though does not fully eliminate, this institutional variation. ${ }^{5}$

\footnotetext{
${ }^{3}$ We use "sector" to distinguish between two-year and four-year colleges. Some research and organizations (Department of Education) refers to "sector" as the difference between public and private colleges.

${ }^{4}$ We recognize that PSAT score is not the only measure of ability of a student or college, but for ease of exposition, we will use "ability" interchangeably with our measures that rely on PSAT scores.

${ }^{5}$ The authors note that controlling for average group characteristics also partially controls for selection on unobservables under reasonable assumptions and provides a lower bound of the variation in school quality (Altonji
} 
We address selection into sector and peer quality by controlling for a rich set of college and student controls. Like previous researchers, we observe that recent high school graduates that start at four-year colleges are approximately 50 percentage points more likely to earn a bachelor's degree within six years than those starting at two-year colleges. Approximately half of this gap remains after controlling for average peer PSAT scores and own student PSAT score. Thus even comparing students with the same test scores and attending institutions with similarachieving peers, those attending a two-year institution are 29 percentage points less likely to earn a bachelor's degree. Both own and peer ability, as measured by PSAT score, are strong predictors of degree attainment, though own ability is relatively more important in the two-year sector and peer ability is relatively more important in the four-year sector. These broad patterns are quite robust to extensive student and institutional controls, including measures of student aspiration to earn a bachelor's degree. The implication is that while peers and resource differences are important contributors to the low BA attainment rate of students starting at community colleges, other factors such as structural barriers to transfer may be equally important.

This paper proceeds as follows. The next section delineates the possible reasons that twoyear students have lower BA attainment rates than four-year students. Section 3 introduces our data and analytic sample. Section 4 describes the new measure of peer quality- average PSAT of students at each college -and documents the variation in peer composition across and within sectors. As this measure of peer quality in the two-year sector was not previously available, we anticipate that this section may be of interest in and of itself. Given the importance of overcoming selection in inferring causality, Section 5 examines the determinants of student

and Mansfield, 2014). So the reduction in college quality effects observed could be because of selection or a direct role of peer characteristics in explaining institutional quality. 
sorting into sector and college quality explicitly. Empirical methods and our main results on degree completion are presented in Section 6. Section 7 concludes with a discussion of the implications.

\section{Peers, Resources, Transfer, or Selection?}

Prior research on the effect of starting at a two-year versus four-year college is mostly silent on the underlying mechanism. There are at least three broad explanations. First, measured college quality (including inputs such as peer ability or instructional spending) is significantly lower at two-year colleges than four-year colleges. A large literature suggests that college quality - broadly defined - has an important role in promoting student success in the four-year sector (Light and Strayer, 2000; Cohodes and Goodman, 2014; Long 2008; Smith 2013) though the evidence on the two-year sector is thin and less positive. ${ }^{6}$ Both Stange (2012) and Bound, Lovenheim, and Turner (2010) find no effect of additional spending in the community college sector on students' attainment.

The academic achievement of students' peers is a particular component of quality that could influence student achievement in higher education, either directly through peer-to-peer interaction or indirectly by improving the efficiency of teaching and educational production. ${ }^{7}$ For instance, Carrell, Fullerton, and West (2009) find large effects of being assigned to higherachieving peers at the Air Force Academy. Unlike prior work that focuses on randomized roommate assignment and finds small or modest peer effects (Sacerdote, 2001; Zimmerman, 2003; Stinebrickner and Stinebrickner, 2006), their setting alters students' entire cohort of peers,

\footnotetext{
6 There is also a larger literature that examines the effects of college quality on earnings: Black and Smith (2004), Dale and Krueger (2002, 2011), Hoekstra (2009), Saavedra (2008), Brewer Eide and Ehrenberg (1999). These studies also mostly ignore two-year colleges.

${ }^{7}$ For broad surveys of the evidence on and challenges to estimating peer effects in education see Sacerdote (2011; 2014). A more theoretical treatment is provided in Epple and Romano (2011). Winston and Zimmerman (2004) discuss this issue specifically in the context of higher education.
} 
akin to switching colleges. In fact, the existence of peer effects helps explain otherwise anomalous pricing, admissions, and competitive behavior of institutions and the extent of stratification observed in the higher education system (Winston and Zimmerman, 2004). Yet we know little about the importance of broad measures of peers to explaining differences in student outcomes among community college students. Given that community colleges do not employ selective admissions, among other differences, the role of peer effects could be quite different than in the four-year sector.

A second class of explanation is that students in the two-year sector face additional structural barriers not encountered by four-year students, namely, the need to transfer institutions in order to earn a bachelor's degree. Transferring requires additional college and program search and application, could result in the loss of credits already earned, and often disrupts students' nonacademic lives and support by requiring students to move. Few of these barriers confront students that are transitioning from lower to upper division status at four-year colleges and universities. Though articulation agreements and guaranteed admissions programs aim to ease this transition, there is not strong evidence of their effectiveness (Anderson, Sun, and Alfonso, 2006; Roksa and Keith, 2008)

Lastly, it could be that students attending two-year colleges have traits or intentions that make them less likely to complete degrees than those starting at four-year colleges. Thus the lower BA attainment rate of community college students could merely reflect selection and not the causal effect of initial sector per se.

In this study we aim to isolate the contribution of the first factor to degree attainment, with a specific focus on the role of peer student ability, which has not been explored previously.

\section{Data Sources and Analytic Sample}




\subsection{Data Sources}

Our main data source comprises records of high school students who took the Preliminary SAT/National Merit Scholarship Qualifying Test® (PSAT) merged to college enrollment information from the National Student Clearinghouse (NSC). Both were obtained from the College Board, who administers the PSAT and merged on NSC records for all PSAT takers.

The PSAT is a standardized test that helps students determine their level of readiness for college, be it through inherent ability or achievement, and also determines eligibility for various scholarships. ${ }^{8}$ In 2004, 2.9 million students took the test, approximately 1.4 million of which were high school juniors (the 2006 cohort in our sample). In contrast, approximately 1.5 million students took the SAT in 2006 (1 million seniors) and a similar number took the ACT. Thus the number of students taking the PSAT is quite a bit higher than either SAT or ACT in isolation. In 2004, 54.8\% of junior test takers were female and $34 \%$ of respondents were non-white. Participation in the PSAT varies by state and district, as it is mandatory in Maine and Delaware and numerous districts. Our analysis uses all students who took the PSAT and graduated high school from 2004 to $2006 .^{9}$

PSAT has three sections- math, critical reading, and writing- each ranging from a score of 20 to 80 . For this analysis, we focus on the math and critical reading scores, which are the two subscores most comparable to the SAT and hence our composite PSAT ranges from 40 to 160. The mean score among the 2004 cohort is approximately 49 in math and 48 in critical reading

\footnotetext{
${ }^{8}$ We use the term "ability” throughout but PSAT may not measure something like IQ, but rather, measure achievement, motivation, and subject matter learned- all of which may play a role in peer effects.

${ }^{9}$ We don't actually know whether the student graduates high school but it is based on their expected graduation date, as self-reported on all College Board assessments.
} 
and a combined average of $94 .{ }^{10}$ In all analysis we standardize these composite test scores to have a mean of zero and standard deviation one in the population of test-takers separately in these three cohorts.

Along with the student's PSAT scores, these data also include high school GPA, basic demographics, home zip code, and enrolled high school. ${ }^{11}$ Using home zip code, we merge on the time-invariant population and percent of population with a bachelor's degree or higher, along with the time-varying county unemployment rate. ${ }^{12}$

Institution of first enrollment for these PSAT-takers is obtained from the National Student Clearinghouse (NSC), which collects postsecondary enrollment information on more than 94 percent of students enrolled in U.S. postsecondary institutions. ${ }^{13}$ Data from the NSC allow us to observe which college, if any, a student enrolls in after high school graduation and also track transfer and completion. The data were merged with NSC in 2012 for the 2004 and 2005 cohorts and 2013 for the 2006 cohort. Thus we observe degree completion up to eight years after high school graduation for the 2004 cohort and seven years for the remaining cohorts, though, we primarily focus on six year graduation rates.

From Integrated Postsecondary Education Data System (IPEDS),we assemble data on college characteristics, including tuition, expenditures, enrollment, percent of part-time students, percent of students who are under 25, latitude and longitude, and sector (two-year or four-year, public or private, and not-for-profit or for-profit). These are used to create measures of the

\footnotetext{
${ }^{10}$ This is using the students' latest attempts. More details on PSAT score distributions can be found http://research.collegeboard.org/programs/psat/data/cb-jr.

${ }^{11}$ High school GPA and demographics are self-reported by the student. Self-reported income is only available for students who also took the SAT.

${ }^{12}$ Unemployment rates come from the Bureau of Labor Statistics and population and educational attainment comes from the Census Bureau's decennial census.

${ }^{13}$ A large fraction of non-participating colleges are for-profit institutions. For more information on the limits of NSC, see Dynarski, Hemelt, and Hyman (2013).
} 
characteristics of colleges attended and of colleges in close proximity to students during high school. We also collect the population and percent of population with a bachelor's degree or higher for the zip code in which each college is located, along with the county level unemployment rate. ${ }^{14}$ Finally, using college location information we construct measures of the community and higher education system surrounding each college, including the average PSAT score of students living within 25 miles, the average PSAT score of nearby colleges, and proximity to and characteristics of nearby two-year and four-year colleges.

\subsection{Analytic Sample}

We start with the universe of students who took the PSAT and graduated high school between 2004 and 2006. We make several exclusions in order to construct our analytic sample, starting with the exclusion of students who enroll in a college where fewer than 50 students who took the PSAT across the three cohorts. This ensures that the calculated average PSAT of students at each college is a relatively stable measure of peer aptitude. ${ }^{15}$ We also exclude students who do not enroll in college or enroll in a for-profit college. Finally, we exclude students who are missing some key variables, such as zip code, high school GPA, and tuition and expenditures at the enrolled colleges. After these exclusions, we make sure we have a balanced panel of colleges across cohorts.

Table 1 contains summary statistics for the final sample of 3.36 million students, separately by sector of first enrollment. Our sample is quite comparable to a nationallyrepresentative sample of 2004 high school graduates that enroll in public and non-profit colleges, so our results are likely to generalize to all "traditional-age" entering college students in the US.

\footnotetext{
${ }^{14}$ These data are collected from the Bureau of Labor Statistics and Census Bureau, but only the unemployment varies over time.

${ }^{15}$ Requiring fewer or more students or using a count in separate years rather than across years does not substantively change our results. We combine cohorts across the three years since students interact and learn with different cohorts in college and students can delay entry after high school.
} 
However, it is important to note that our sample does not reflect the average student in community college. In addition to "traditional-age" students, community colleges serve older students, working professionals, those who took a few years off, or those who did not take the PSAT- none of which are in our sample. ${ }^{16}$ Thirty seven percent of students starting at two-year schools ultimately attend a four-year school and sixteen percent ultimately receives a bachelor's degree within six years. The bachelor's degree attainment rate is significantly higher (68\%) among students who start at a four-year institution. Though this difference in BA attainment rate across sectors is striking, this table also suggests several possible explanations. One plausible explanation is selection. As has been documented previously, students attending community college have lower achievement test scores and high school grades, are disproportionately from communities with low educational attainment, and are more likely to be underrepresented minorities. These students may, independent of sector attended, be less likely to attain a BA degree. However, students at community colleges also experience much lower levels of educational resources; spending per student is $\$ 5,300$ lower in the two-year sector and average peer aptitude (as measured by average PSAT) is also much lower (and discussed in much more detail in the next section). They also tend to live further from four-year colleges, perhaps impeding successful transfer.

\section{A New Measure of Institutional Quality}

\footnotetext{
${ }^{16}$ Table A1 in the appendix compares our analysis sample to two nationally-representative samples of students separately for 2-year and 4-year enrollees: 2004 college-going high school seniors from the Education Longitudinal Study of 2002 and 2003/2004 beginning postsecondary students from the Beginning Postsecondary Study 2004/2009. Our analysis sample is quite comparable in terms of BA attainment, transfer behavior, sex and racial composition, and high school GPA to recent high school graduates nationally. Our sample has higher rates of attainment and transfer than all entering college students (the BPS sample), which includes more students who delayed college entrance after high school.
} 
The merged PSAT and NSC data permit us to construct measures of average student achievement of traditional-aged students at the majority of public colleges in the U.S., as well as many private non-profit ones. Historically, this has been impossible because many two-year college students do not take the SAT or ACT and these scores are not reported to or by most two-year institutions, even among students that do take these exams.

For each two- and four-year college, we calculate the average PSAT score of enrolled students who took the exam between 2004 and 2006, standardized by the mean and standard deviation of all test-takers in each cohort. After restricting the sample to students who attend colleges that have at least 50 students who took the PSAT, this leaves 695 out of the 1061 public two-year (community) colleges, 434 out of the 711 public four-year colleges and universities, and 621 out of the 1,662 private non-profit four-year colleges and universities. ${ }^{17}$

By construction, our measure of peer ability captures the characteristics of the recent high school graduates who attend each school, but does not necessarily reflect the characteristics of the older students at the school or students who didn't take the PSAT. Many institutions, particularly two-year colleges, serve older students. As one check of the validity of the average PSAT score as a measure of peer ability, we compare average PSAT to average SAT score at the institution level among four-year colleges. These two measures are highly correlated (correlation coefficient $\approx 0.9$ ), yet importantly the average PSAT score is available for more institutions, particularly two-year colleges. We also examine the robustness of our results to alternative moments of the PSAT distribution within colleges: the median, $25^{\text {th }}$, and $75^{\text {th }}$ percentiles. Finally,

\footnotetext{
${ }^{17}$ The official counts come from IPEDS. We exclude for-profit colleges, most of which do not fit our criteria. Table A2 in the appendix compares the characteristics of institutions included and excluded from our sample based on the requirement for 50 PSAT test-takers. Excluded institutions tend to be smaller, more likely to be private and more expensive (among 4-year colleges), and serve older students. Again this suggests that our analysis reflects the experience of traditional-age students (and colleges that serve traditional students) then those of older students.
} 
in some analyses we control for other characteristics of the student body (fraction part-time, fraction less than 25 years old) which may be correlated with average PSAT.

\subsection{Variation in Peer Quality}

Figure 1 depicts the distribution of average PSAT score across public two-year and fouryear colleges in the U.S. Four facts are noteworthy. First, there is substantial variation in student ability across colleges. Some colleges enroll very high-ability students while others enroll mostly low-ability students. This is well documented and is the motivation for much of the prior research on college quality. Second, the distribution of four-year colleges is shifted to the right of that of two-year colleges. The average ability of incoming students at four-year colleges is higher than that of two-year colleges. Again, this is well documented and motivates the need to address selection into the two-year sector when trying to examine the effect of sector. Third, there is substantial heterogeneity among two-year colleges. Previous research has mostly treated all twoyear colleges as a homogeneous outside option for bachelor's degree aspiring students, ignoring any variation in peer quality within the two-year college sector. Lastly, there is non-trivial overlap between the two sectors, with some two-year colleges attracting students (on average) that are as high achieving or even more high-achieving than those at four-year colleges. This is a new fact and one that has not previously been documented.

Figure 2 shows the distribution of average PSAT scores at each institution separately for each state and sector. While there is variation across states, clearly much of the variation in peer quality operates between institutions within states. Furthermore, almost all states have public two-year colleges that attract students that are as high-achieving as some of the less-selective four-year colleges in the state. This overlap across sectors within states will be our main source of variation to identify the effect of peer composition on student achievement conditional on 
sector. When restricting our analysis to public colleges, as in Appendix Figure 2, we see similar variation and overlap across sectors within states.

\subsection{Correlates of Average PSAT of Colleges}

To better understand the correlates of this variation, we fit simple OLS models of the relationship between the average PSAT score of students at college $j$ and various characteristics of the college, its neighboring colleges, and the local area in which it resides. We are primarily interested in three categories of factors: (1) policy characteristics under the control of the colleges themselves, such as tuition and spending; (2) market characteristics such as number, proximity, and characteristics of nearby two-year and four-year colleges (public and private); and (3) local population characteristics such as population size, income, educational attainment, and achievement of students in nearby high schools. On average, two-year colleges in our sample (see Appendix Table A2) have an average normalized PSAT of -0.37 , spend $\$ 4,032$ per student, and charge in-state students $\$ 2,823$ per year. They are 28.6 miles (on average) from the nearest other two-year school, 18.9 miles from the nearest four-year school, have 2.4 other two-year colleges and 5.4 four-year (public or private non-profit) colleges within 25 miles. Four-year colleges have higher-achieving students (average PSAT is 0.246), spend more on their students, and charge higher tuitions.

One of the strongest predictors of community college average PSAT is the average PSAT of students residing nearby (see Appendix A3). That is, community colleges whose local student population is high achieving also tend to attract high-achieving students. This is true without local area controls or with state and county fixed effects. In fact, the average PSAT of nearby high school students explains one-third of the variation in community college average PSAT. Our analysis also suggests that two-year colleges located far from four-year colleges tend to 
attract higher-ability students; being ten miles further from the nearest four-year college is associated with an average PSAT score that this 0.017 standard deviations higher. Average student ability is also higher at two-year colleges that have fewer nearby competitors (both twoyear and four-year) within 25 miles. This pattern is consistent with a model of sorting where two-year colleges serving larger markets are better able to attract high-achieving students. Twoyear colleges that compete against more four-year colleges for students, by contrast, attract students of lower average ability. Tuition and expenditure, of geographic competitors or the colleges themselves, generally have a weak relationship with average student ability.

\section{Student Sorting}

\subsection{Empirical Specification}

We first assess the factors that determine the sorting of students into colleges at the individual-level. We view this both as informative in its own right and to identify sources of bias in our analysis examining student outcomes. Any factor that influences sector and peer quality choice that may also influence degree attainment is potentially a source of bias if not controlled for.

We estimate reduced-form models of sector and college choice as represented in Equation (1). ${ }^{18}$

\footnotetext{
${ }^{18}$ We view this as an approximation to a multinomial choice model, where students choose from a large set of colleges, each with characteristics that vary by college (e.g. sector or college quality) or collegestudent match (e.g. distance). In the full choice model, the probability that a student chooses any one college will be a function of the characteristics of the individual, the characteristics of the college in question, and the characteristics of all other colleges. Thus the characteristics of the college chosen by individual $\mathrm{i}$ will be a complex non-linear function of individual traits and the traits of all colleges in a student's choice set. Our reduced-form model can be thought of as a simplified linearization of this more complex model.
} 


$$
D_{j(i)}=\gamma_{0}+\gamma_{1} \text { PSAT }_{i}+\gamma_{2} X_{i}+\gamma_{3} \text { Area }_{i}+\gamma_{4} \text { ChoiceSet }_{i}+e_{i j}
$$

Let $D_{j(i)}$ denote the characteristic of college $j$ that is chosen by student $i$. We are primarily interested in two characteristics: $4 Y E A R_{j(i)}$, an indicator denoting four-year institutions, and $\overline{P S A T}_{j(i)}$, the average PSAT score at school $j{ }^{19}$

Most of the literature focuses on the role of student characteristics, such as test scores, high school grade point average, race, income, and parent background as key determinants of sector and college quality. We include these as $\operatorname{PSAT}_{\mathrm{i}}$ and $\mathrm{X}_{\mathrm{i}}$, respectively. To assess the importance of environmental factors that may also influence student college choices, we also include a vector of area characteristics $\left(\right.$ Area $\left._{i}\right)$, including the average test scores of the high school attended by students, characteristics of the students' zip code area (population and fraction of population with a bachelor's degree), county unemployment rate and either state or county fixed effects. Finally, we assess the role of characteristics of the college choice set available to students, ChoiceSet $_{i}$, which includes the distance to, concentration of, and resources of nearby two- and four-year colleges.

Unobserved determinants of college choice (peers, teachers, parent social networks) are likely to be correlated among students attending the same high school, making high school the natural level at which to cluster standard errors. Furthermore, several of our key variables are either defined at the high school level (e.g. high school average GPA) or get most of their variation across high schools (e.g. proximity to nearby colleges). This again supports the decision to cluster standard errors at the level of high school.

\footnotetext{
${ }^{19}$ The subscript $j(i)$ makes explicit the school-level characteristic is a choice by individual (i). We subsequently drop the (i) subscript from college-level characteristics when talking about the effects of college characteristics, though the choice nature of these variables remains implicit.
} 


\subsection{Results}

Tables 2 and 3 present evidence on the determinants of sector and college quality choice, respectively. As has been documented previously, in Table 2 we find that higher-achieving students (higher PSAT scores and high school GPA) are more likely to attend four-year colleges directly after high school. Column (2) adds characteristics of high school attended and the local area. These environmental factors are very important: students attending high schools with high achieving peers or whose community has many college graduates are much more likely to attend four-year colleges. These patterns (and magnitudes) are quite similar even when state or county fixed effects are controlled for (specifications 3 and 4). Specification (5) adds characteristics of students' college choice set. As expected, students that have more two-year colleges in close proximity or who live closer to a two-year college are more likely to attend two-year college, while the opposite is true for those living near more four-year colleges. Expenditure of nearby colleges has an opposite effect than expected: the sector that is better resourced tends to attract fewer nearby students. We also find that sector choices of high achieving students are less sensitive to distance to and density of nearby colleges. ${ }^{20}$ In results not reported, estimates are virtually identical when the tuition of the nearest 2-year and 4-year colleges are included. ${ }^{21}$

Table 3 presents the same specifications, but with average PSAT of the college attended as the outcome. Models are estimated separately by sector. There is evidence of assortative matching between colleges and students: higher-achieving students tend to attend college with other high achieving students. Underrepresented minorities attend colleges with lower-achieving peers, even after controlling for own achievement. This is true in both sectors, though there are striking differences in the importance of student characteristics to student sorting across sectors.

\footnotetext{
${ }^{20}$ These results are reported in Appendix Table A4.

${ }^{21}$ Tuition of the closest four-year school is negatively related to the likelihood of enrolling in a four-year college, but tuition of the closest two-year is unrelated.
} 
Student achievement and demographics (Specifications 1 and 5) explain $40 \%$ of the variation in chosen peer quality of individuals at four-year institutions, but only $18 \%$ in the two-year sector. Student achievement (PSAT and high school GPA) in particular is a much stronger predictor of the peers experienced by students in the four-year sector, almost certainly reflecting the fact that many four-year schools have an admissions process that is at least modestly selective. On the other hand, local area characteristics, such as the average PSAT of students' high schools and unobserved state and county characteristics are much more important in the two-year sector. ${ }^{22}$ The final column includes characteristics of nearby colleges. Here the predictions are less clearcut than in sector choice. Among students attending a two-year college, having more four-year colleges nearby (or having the closest one closer) is associated with attending a community college with lower peer ability. This is particularly true for high-achieving students, as reported in Appendix Table A4. Again, estimates are virtually identical when the tuition of the nearest 2year and 4-year colleges are included.

Our analysis thus provides evidence of sorting: more capable students tend to start at four-year colleges and also attend institutions with high-achieving peers, though the latter effect is much weaker among students opting to attend two-year college. This finding that studentdriven sorting is much more prominent for four-year college students than those attending community college echoes prior work by Stange (2012). Many four-year colleges are at least modestly selective (based on student achievement) while two-year colleges have open enrollment and students usually just attend the closest one.

\footnotetext{
${ }^{22}$ Including county FEs instead of state FEs somewhat attenuates the coefficients on HS Average PSAT and percent of population with a BA and increases the R-squared to 0.651 in the 2-year sector, but otherwise has little effect on coefficient estimates. For the four-year sector, a specification with county FEs is identical to that with state FEs, suggesting that unobserved local factors have virtually no impact on college choice among 4-year college students. These patterns are consistent with students largely attending community college in their county, so county FEs explain much of the variation in college quality among community college students. These results are available from the authors upon request.
} 
The implications for our empirical analysis of student outcomes are two-fold. First, it will be important to control for student ability and local area characteristics (particularly high school average PSAT) as they influence students’ college and sector choice and are also likely to impact outcomes. Second, non-random selection into college quality may be less problematic in the twoyear rather than four-year sector, as selection appears to be driven more by community rather than student characteristics. We elaborate on these issues in our discussion of empirical model below.

\section{Postsecondary Attainment}

\subsection{Empirical Specification}

To assess the effects of sector and peer quality on degree completion, we estimate Equation (2):

$$
Y_{i j}=\beta_{0}+\beta_{1} 4 Y E A R_{j}+\beta_{2} \overline{P S A T}_{j}+\beta_{3} P S A T_{i}+\beta_{4} X_{i}+\beta_{5} Z_{j}+e_{i j}
$$

Our primary outcome $\left(Y_{i j}\right)$ is an indicator for completion of a bachelor's degree within six years, though we also examine completion of any degree (associate's or bachelor's degree) and completion within different time windows. Our primary explanatory variables are $4 Y E A R_{j}$ and $\overline{P S A T}_{j}$, which are an indicator for attending a four-year institution and the average PSAT score at school $j$, respectively. We include students' own PSAT score and a wealth of individual characteristics $\left(X_{i}\right)$, including sex, race/ethnicity, high school GPA, and several characteristics of the students' home area. State fixed effects are included in all regressions. We also control for other characteristics of the institution $\left(Z_{j}\right)$, including control, in-state and out-of-state tuition, expenditures per student, enrollment, percent of part-time students, and percent of students who are under 25. 
The first parameter of interest, $\beta_{1}$, measures the combined effect of all sector attributes, net of those included in the model such as average student ability $\left(\overline{P S A T}_{j}\right)$ or expenditure per student (included in $Z_{j}$ ). $\beta_{1}$ is identified by students with similar characteristics attending schools with similar peers, yet in different sectors. Figure 2 demonstrated that many states have some two- and four-year institutions with comparable average student ability, which form the basis for identifying $\beta_{1}$.The second parameter of interest is $\beta_{2}$, the effect of average peer ability on own educational attainment, which is permitted to differ by sector and student ability. The effect of peer quality is identified from differences in outcomes between observably similar students attending schools with different levels of peer ability in the same sector.

Unbiased estimation of these parameters requires that sector and peer quality are uncorrelated with other (unobserved) determinants of degree outcomes, at both the student and college level. For example, if among students of a given ability level, disadvantaged students were more likely to attend schools with lower-ability peers, then any lower attainment for this group may be due to the economic disadvantage, rather than lower peer quality. Exploiting very rich observable information about the students and colleges, we rely on a selection-onobservables assumption to overcome the inherent selection bias problems, as is done in much of the prior literature (Long and Kurlaender, 2009; Stange, 2012; Reynolds, 2012; Bound, Lovenhiem, Turner, 2010). ${ }^{23}$ The results in Table 3 suggest it is important to control for student ability and local area characteristics (particularly high school average PSAT) as they influence students' college and sector choice and are also likely to impact outcomes. However, nonrandom selection into higher $\overline{P S A T}_{j}$ colleges may be less problematic in the two-year rather than

\footnotetext{
${ }^{23}$ We do not attempt to employ an instrumental variables procedure as we have two potentially endogenous variables (4YEAR $R_{j}$ and $\overline{P S A T}_{j}$ ) but the standard proximity instruments used by Long and Kurlaender (2009) and others do not impact $\overline{P S A T}_{j}$ in obvious ways that satisfy the exclusion restriction.
} 
four-year sector, as selection appears to be driven more by community rather than student characteristics. Nonetheless, our estimate of $\beta_{2}$ may include the contribution of unobserved student characteristics in addition to the direct effect of peer quality. Similarly, since controls for observables are unlikely to completely eliminate unobserved student differences across sectors, our estimate of $\beta_{1}$ may combine factors we are interested in (e.g. transfer and articulation policies, psychic or informational barriers to transfer) with student selection. However, Altonji and Mansfield (2014) show that controlling for average student observables (e.g. $\overline{P S A T}_{j}$ ) may actually account for sorting on unobservables under a standard sorting model. This suggests that our conclusion about the importance of factors beyond peers in explaining the four-year versus two-year BA attainment gap may still hold even after accounting for selection on unobservables. ${ }^{24}$

We generalize our basic specification in two important ways. First, to examine differences in the importance of peer quality between sectors, in many specifications we interact both average PSAT of college with sector and own PSAT with sector. To our knowledge, the relationship between average peer ability and educational attainment has not been previously documented for the two-year sector. Second, we include interactions between own PSAT and average PSAT of college to test for complementarity in peer effects. That is, do relatively able students benefit more from interacting with high-ability peers than less-able students? Though the relationship between peer quality and degree completion at four-year colleges has been welldocumented (Long, 2009; Smith, 2013), such a relationship has not been estimated for two-year colleges.

\subsection{Results}

\footnotetext{
${ }^{24}$ In this case, the coefficient on $\overline{P S A T}_{j}$ is not interpretable as the effect of peer ability, as it combines the effects of peers and selection on unobservables.
} 
Figure 3 presents a graphical illustration of our main findings. The figure plots the fraction of students at each college that earn a bachelor's degree within six years of high school graduation as a function of the average PSAT score of students at the college, separately by sector. Solid lines are smoothed plots from a locally-weighted regression and the 95\% confidence interval is shaded around the plots. There is a strong relationship between average student ability and graduation rates in both sectors. A one standard deviation in mean PSAT score is associated with a 20 to 25 percentage point gain in the graduation rate. There is also a striking difference in average graduation rates across sectors: students at four-year colleges are much more likely to earn a degree. To preview our main finding, Figure 3 demonstrates that this cross-sector gap is large even at colleges with similar levels of average peer ability. Four-year colleges have graduation rates about 25 percentage points higher than two-year colleges whose students have the same average PSAT. This is our first suggestive evidence that the performance gap between the two sectors reflects a combination of both peer ability and other non-peer factors.

Table 4 presents OLS estimates of equation (2) with an indicator for receiving a bachelor's degree within six years as the outcome. The first two columns present simple regressions of the outcome on mean college PSAT and a sector indicator, respectively. ${ }^{25}$ Combining all colleges, a one standard deviation increase in mean PSAT score is associated with a 39.8 percentage point increase in likelihood of receiving a bachelor's degree. The comparable figures for attending a four-year (rather than two-year) college is 51.5 percentage points. In line with the previous literature, these estimates suggest that sector and peer quality have an incredibly strong relationship with student success. Each of these effects are diminished, though still remain large and significant, when both characteristics are included simultaneously (column

\footnotetext{
${ }^{25}$ All models also include year and state fixed effects.
} 
3). Approximately 40 percent of the bachelor's degree attainment gap between the sectors can be explained by average peer quality. This changes little when student PSAT and the average PSAT of students' high school are included as controls, though both of these factors are individually very predictive (column 4).

Our preferred specification is (5), which permits the effect of own and peer PSAT score to vary by sector and also includes a full set of individual controls, including sex, race/ethnicity, high school GPA, and characteristics of the local population (size, unemployment rate, educational attainment). Own PSAT is a stronger predictor of success at two-year colleges than at four-year colleges (coefficient on student PSAT X four-year college interaction is negative). However, the effect of average peer quality is stronger in the four-year sector. A one standard deviation increase in peer ability is associated with a 3 percentage point increase in bachelor's degree attainment at two-year colleges (95\% CI $=0.3$ to 5.2 percentage points) and a 14 percentage point increase in bachelor's degree attainment at four-year colleges. Starting at a twoyear college is associated with a 32.5 percentage point lower rate of BA attainment $(95 \% \mathrm{CI}=$ 30.9 to 34.2 percentage points).

To examine effect heterogeneity, specifications (6) and (7) permit the effect of peer quality to differ with student own ability. If own and peer ability are complements in educational production, then we expect the interaction to be positive. Specification (6) imposes that this peer complementarity is the same in the two- and four-year sectors, while (7) permits the complementarity to differ by sector. We see evidence of complementarity in the two-year sector, but the opposite in the four-year sector. Two-year college students with high test scores benefit the most from exposure to high-ability peers (consistent with complementarity in production), while the opposite is true at four-year institutions. 


\subsection{Robustness Tests}

Sector and average student ability are only two of the potentially large number of important attributes of colleges that determine student success. Table 5 probes the sensitivity of these patterns to controls for various other institutional characteristics. ${ }^{26}$ The first column repeats our final specification from Table 4. In column (2) we control for instructional spending per student. Accounting for spending differences between institutions has little impact on our estimates, as aggregate spending has minimal association with student outcomes once sector, peer ability, and student characteristics are controlled for. ${ }^{27}$ Specification (3) controls for a rich array of other institutional characteristics, including in-state and out-of-state tuition, percent of students who are part-time, number of students, and percent of students who are under 25 years old in order to isolate the effect of average peer ability and sector from these other college-level factors. Though the effect of sector is diminished by about one-third, it remains large and significant. Interestingly, average peer ability still remains a stronger predictor of outcomes at four-year schools than two-year schools, while own ability is more important at two-year schools. The pattern of heterogeneity is also unchanged: high ability students benefit the most from improvements in peer quality at two-year schools, while low ability students benefit the most from peer quality at four-year schools.

Columns (4) through (6) further investigate the robustness to controlling for students' four-year intentions (proxied by SAT score sending) and restricting the sample in various ways. We first restrict to only "SAT states" - the 22 states in which more students take the SAT than the ACT- so as to mitigate some of the selection bias that could stem from non-random PSAT

\footnotetext{
${ }^{26}$ Appendix Table A5 also demonstrates that our results are nearly identical when using various moments of the PSAT distribution within colleges, including the mean (our base measure), median, $25^{\text {th }}$ percentile, and $75^{\text {th }}$ percentile.

${ }^{27}$ In fact, spending is negatively associated with outcomes in the two-year sector. This result was found in some of the specifications reported by Stange (2012) and also Bound, Lovenhiem, and Turner (2010).
} 
test-taking. Results are largely unchanged. We next restrict to the 9 states where more than $75 \%$ of high school graduates take the PSAT. ${ }^{28}$ In this specification, the coefficient on the average PSAT of the college drops from 0.0551 to 0.036 and is only marginally significant. While the coefficients are not statistically different from one another, it may suggest that the previous results suffered from selection bias. The alternative explanation to selection bias is that the 9 states differ in other ways, such as student composition or articulation agreements between colleges.

The estimates from our final specification with the full sample (Table 5, specification 4) suggest that both peer ability and sector have independent effects on graduation. For a student in the middle of the PSAT distribution, starting at a four-year college is associated with a 20.7 percentage point increase in the likelihood of earning a bachelor's degree within six years (95\% $\mathrm{CI}=18.0$ to 23.3 percentage points). A one standard deviation increase in mean PSAT score of peer students is associated with a $5.3(10.1)$ percentage point increase among students attending a two-year (four-year) school (95\% CI = 3.0 to 7.6 percentage points for two-year students). Own ability also matters, though less so for students at four-year schools. The fact that sector is still so important even after accounting for peer ability, expenditure, and several other college attributes suggests that structural factors such as credit transfer policies and the disruption of having to relocate to another college in order to earn a degree are important.

\subsection{Alternative Outcomes}

\footnotetext{
${ }^{28}$ This 75\% threshold corresponds to the fraction of high school graduates that go on to college and also happened to be a natural break in the data. This is not to imply that all college-goers in these states took the PSAT, but it is likely to be a very high fraction did.
} 
Table 6 examines other outcomes. The first three columns examine bachelor's degree attainment over different time horizons (our base model using 6 years is repeated in column 2). ${ }^{29}$ Most of our results are qualitatively similar, though stronger when looking at a longer time horizon. This is because few students with average PSAT scores and attending colleges of average quality actually graduate within four years, so sector differences widen over longer time horizons. Of course, a bachelor's degree may not be the goal of many students that enter twoyear colleges. The next two sets of columns examine attainment of an associate's degree or any degree (associate's or bachelors). Much of the attainment gain of starting at a four-year institution or attending a two-year college with more able peers operates via shifting students from associate's to bachelor's degrees. Attending a two-year college with higher achieving peers is associated with lower rates of associate's degree attainment, particularly for high-ability students. Starting at a four-year institution also makes it extremely unlikely that students will earn an associate's degree, which is unsurprising given that only $2 \%$ of students starting at a four-year institution in our sample receive an associate’s degree. Columns (7) to (9) examine the outcome of whether students earn any degree (associate’s or bachelor's). Starting at a four-year institution is ultimately associated with a 7-8 percentage point increase in the likelihood of earning any degree, but peer quality only influences degree attainment in the four-year sector. However, students' own ability is a more important predictor of degree attainment in the twoyear sector rather than the four-year sector.

\section{Interpretation and Discussion}

Wide differences in student outcomes exist across sectors of higher education and between institutions within sectors. In fact, closing these performance caps between institutions

\footnotetext{
${ }^{29}$ The 8-year completion rates only use the 2004 cohort but previous results are not sensitive to only using 2004 cohort, thus ruling out cohort effects.
} 
and sectors has been one consistent theme of many higher education policies undertaken recently by the Obama Administration and many states. Performance funding is being discussed, advocated, and enacted by many states that explicitly ties state appropriations to institutional performance and the student outcomes are one of the key inputs into the college ratings scheme recently considered by the Obama Administration. ${ }^{30}$

However, identifying the sources of these outcome differences has been difficult due to limited information about the two-year sector. In this paper we have used a novel dataset on all PSAT test-takers in the U.S. to construct a measure of peer ability that is comparable across sectors and available for many two-year colleges. Our main contribution is to be able to compare institutions within the two-year sector and to compare institutions with similar peers across sectors. Since two-year colleges are generally open admission, almost all previous research on college quality has grouped them together, ignoring any heterogeneity within the two-year sector. Our analysis suggests that this simplification misses a lot: there is substantial variation in peer quality across two-year institutions and some two-year institutions actually attract students that are quite similar to less-selective four-year institutions. This overlap permits us to examine how much of the outcome gap between the two- and four-year sectors is attributable to peer quality, a chief input in educational production. We find that substantial differences in student outcomes exist across sectors even between institutions with similar students. This holds true even after controlling for other observed institutional characteristics, such as spending, tuition, student age, percent part-time, and size. Thus structural factors, such as barriers to transferring between institutions, are likely as (if not more) important an explanation for the sector gap than input differences.

\footnotetext{
${ }^{30}$ http://www.whitehouse.gov/the-press-office/2013/08/22/fact-sheet-president-s-plan-make-college-moreaffordable-better-bargain-
} 
Across several outcomes and specifications, we also find interesting differences in the relative importance of own and peer ability across sectors. In determining bachelor's or any degree attainment, students' own ability is relatively more important in the two-year sector, while peer ability is relatively more important in the four-year sector. One interpretation is that individual traits - such as the ability to navigate a complex transfer process or balance school with other commitments - are more important in the two-year setting, which has less structure and institutional support. By contrast, peers help serve that role at four-year institutions. Regardless of the explanation, this finding suggests that the nature of the production process is different across sectors, an area that should be explored further.

Our results also have implications for understanding college choice and policy, suggesting that the decision on where to enroll is even more nuanced than is typically discussed. The quality of the two-year college, as measured by average PSAT scores, matters, perhaps as much as it does for four-year colleges. Thus, students may not want to consider their local twoyear college as the only alternative, but rather, carefully weigh it against the four-year options and even other two-year options, which may be more distant. Similarly, policies that incentivize two-year over four-year enrollment, such as "free community college," may lower some students' chances of receiving a bachelor's degree, though, it depends on the relative college qualities a student faces.

Our results also have implications for many of the accountability measures currently being discussed. Since these typically target institutions in isolation, they miss an important determinant of two-year college success, such as transfer processes that are largely determined by external institutions or systems. This focus on the performance of individual institutions may thus create incentives for these institutions to target outcomes they have control over, such as 
associate's degree attainment, at the expense of bachelor's outcomes (that depend on other institutions).

Our study has two chief limitations. First, we employ a "selection-on-observables" assumption; unobserved factors (e.g. unmeasured student motivation or preparation) may thus cause us to overstate the independent contribution of sector and own peer ability in explaining BA degree attainment. However, under certain assumptions about the sorting process, our conclusion about the importance of factors beyond peers in explaining the 4-year vs. 2-year BA attainment gap may still hold even after accounting for selection on unobservables (Altonji and Mansfield, 2014). A more focused attempt to isolate the importance of peers in a community college setting using experimental and quasi-experimental variation would be a welcome contribution to the literature on peer effects in higher education, which has focused on university students. A second limitation is one of generalizability, as our analysis necessarily focuses on “traditional-age” college students that enroll shortly after high school graduation. Our sample is quite representative of these types of students, but we are not able to say whether our results generalize to the older students that constitute a large share of community college students. Assessing the importance of peers to these students' success is a second important area for future research. 


\section{References}

Altonji, J. and R. Mansfield, 2014. Group-Average Observables as Controls for Soring on Unobservables When Estimating Group Treatment Effects: The Case of School and Neighborhood Effects.” NBER Working Paper No. 20781. December 2014.

Anderson, GM., J.C. Sun, and M. Alfonso. 2006. Effectiveness of statewide articulation agreements on the probability of transfer: A preliminary policy analysis. Review of Higher Education, 29, 261-291.

Andrews, R., J. Li, and M. Lovenheim, 2012. Quantile Treatment Effects of College Quality on Earnings: Evidence from Administrative Data in Texas. NBER Working Paper No 18068. May 2012.

Black, D. and J. Smith, 2004. How robust is the evidence on the effects of college quality? Evidence from matching. Journal of Econometrics, 121(1-2), 99-124.

Brewer, Dominik, Eric Eide and Ronald Ehrenberg, 1999. "Does it Pay to Attend an Elite Private College? Cross-Cohort Evidence on the Effects of College Type on Earnings.” Journal of Human Resources 34(1): 104-123.

Bound, J., M.Lovenheim, and S. Turner, 2010. Why have college completion rates declined? An analysis of changing student preparation and collegiate resources. American Economic Journal: Applied Economics 2 (July 2010): 129-157.

Bowen, W.G., Chingos, M., \& McPherson, M. 2009. Crossing the finish line. Princeton, NJ: Princeton University Press.

Carrell, S.E., R.L. Fullerton, and J.E. West. 2009. Does Your Cohort Matter? Measuring Peer Effects in College Achievement. Journal of Labor Economics. 27 (3): 439-464.

Cohodes, Sarah, and Joshua Goodman, 2014. "Merit Aid, College Quality and College Completion: Massachusetts’ Adams Scholarship as an In-Kind Subsidy,” American Economic Journal: Applied Economics.

College Board, 2014. “Trends in College Pricing - 2014.” Accessed online 11/13/2014: https://secure-media.collegeboard.org/digitalServices/misc/trends/2014-trends-college-pricingreport-final.pdf

Dale, S. and A. Krueger, 2002. "Estimating the Payoff to Attending A More Selective College: An Application of Selection on Observables and Unobservables." Quarterly Journal of Economics 117(4): 1491-1527

Dale, S. and A. Krueger, 2011. "Estimating the Return to College Selectivity over the Career Using Administrative Earnings Data.” National Bureau of Economic Research Working Paper 17159 
Doyle, W.R. 1999. The effect of community college enrollment on bachelor's degree completion. Economics of Education Review, 28(2), 199-206.

Dynarski,S., S. Hemelt, and J. Hyman, 2013. The missing manual: Using National Student Clearinghouse data to track postsecondary outcomes. NBER Working Paper 19552. October 2013.

Epple, D. and R. Romano. 2011. Peer Effects in Education: A Survey of the Theory and Evidence. in J. Benhabib, A. Bisin and M. O. Jackson (Eds), Handbook of Social Economics, Volume 1B. Elsevier (2011).

Goodman, J., M. Hurwitz, and J. Smith, 2014. "College Access, Initial College Choice and Degree Completion,” Harvard Kennedy School Research Working Paper 14-030.

Hoekstra, M, 2009. The Effect of Attending the State Flagship University on Earnings: A Discontinuity-based Approach. Review of Economics and Statistics 91(4): 717-724.

Kurlaender, M., S. Carrell, and J. Jackson, 2014. The Promises and Pitfalls of Measuring Community College Quality. Paper prepared for Russell Sage Foundation Conference on Higher Education Effectiveness. November 2014.

Leigh, D. and A. Gill, 2003. Do community colleges really divert students from earning bachelor's degrees? Economics of Education Review 22(1), 23-30.

Light, A and W. Strayer, 2000. Determinants of College Completion: School Quality or Student Ability? The Journal of Human Resources, 35, no. 2, 299-332.

Long, M. 2008. “College Quality and Early Adult Outcomes.” Economics of Education Review. 27(5): 588-602.

Long, B.T. and M. Kurlaender, 2009. Do community colleges provide a viable pathway to a baccalaureate degree? Education Evaluation and Policy Analysis, 31(1), 271-296.

Miller, Darwin, 2007. Isolating the Causal Impact of Community College Enrollment on Educational Attainment and Labor Market Outcomes in Texas. SIEPR Discussion Paper No 0633. Stanford University. January 2007.

Reynolds, C. Lockwood, 2012. Where to attend? Estimating the effects of beginning college at a two-year institution. Economics of Education Review 31(2012): 345-362

Roksa, Josipa and Bruce Keith. 2008. Credits, Time, and Attainment: Articulation Policies and Success After Transfer. Educational Evaluation and Policy Analysis. 30(3): 236-254.

Rouse, C.E. 1995. Democratization or diversion? The effect of community colleges on educational attainment. Journal of Business and Economic Statistics, 13(2), 217-224. 
Saavedra, J, 2009. The Learning and Early Labor Market Effects of College Quality: A Regression Discontinuity Analysis. Unpublished working paper. University of Southern California.

Sacerdote, Bruce. 2001 Peer effects with random assignment: Results for Dartmouth roommates. Quarterly Journal of Economics. 116 (2): 681-704.

Sacerdote, Bruce. 2011. Peer Effects in Education: How Might They Work, How Big Are They and How Much Do We Know Thus Far? in E. Hanushek, S. Machin, L. Woessmann (Eds.), Handbook of the Economics of Education, Volume 3. Elsevier (2011)

Sacerdote, Bruce. 2014. Experimental and Quasi-Experimental Analysis of Peer Effects: Two Steps Forward? Annual Review of Economics, 2014 (6): 253-272.

Smith, J. 2013. Ova and Out: Using Twins to Estimate the Educational Returns to Attending a Selective College, Economics of Education Review, 36: 166-180.

Smith, J., M. Pender, and J. Howell, 2013. “The Full Extent of Academic Undermatch,” Economics of Education Review, 32: 247-261.

Stinebrickner, Ralph and Todd R. Stinebrickner. 2006. What can be learned about peer effects using college roommates? Evidence from new survey data and students from disadvantaged backgrounds. Journal of Public Economics 90 (8-9):1435-54.

Stange, K. 2012. Ability sorting and the importance of college quality to student achievement: Evidence from community colleges. Education Finance and Policy 7(1), 1-32.

Winston, G. and D. Zimmerman. 2004. Peer effects in higher education. In C. Hoxby (Ed.), College choice: The economics of where to go, when to go, and how to pay for it. Chicago:

University of Chicago Press (2004).

Zimmerman, David J. 2003. Peer effects in academic outcomes: Evidence from a natural experiment. Review of Economics and Statistics 85(1): 9-23. 


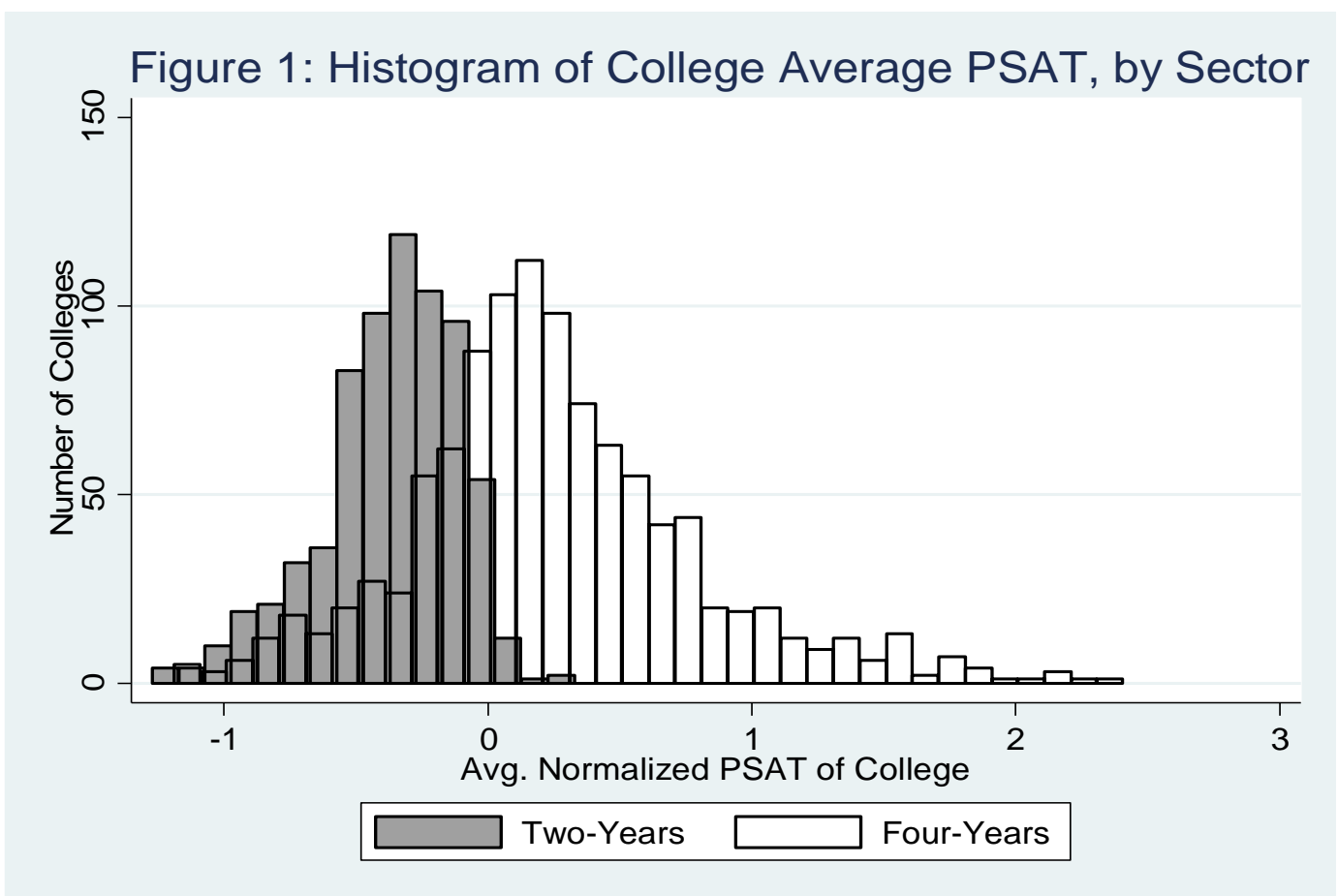

Notes: Figure plots the distribution of average college PSAT score separately by sector. Includes colleges with at least 50 PSAT test-takers combined across the 2004-2006 cohorts. 
Figure 2: Distribution of Average PSAT by State
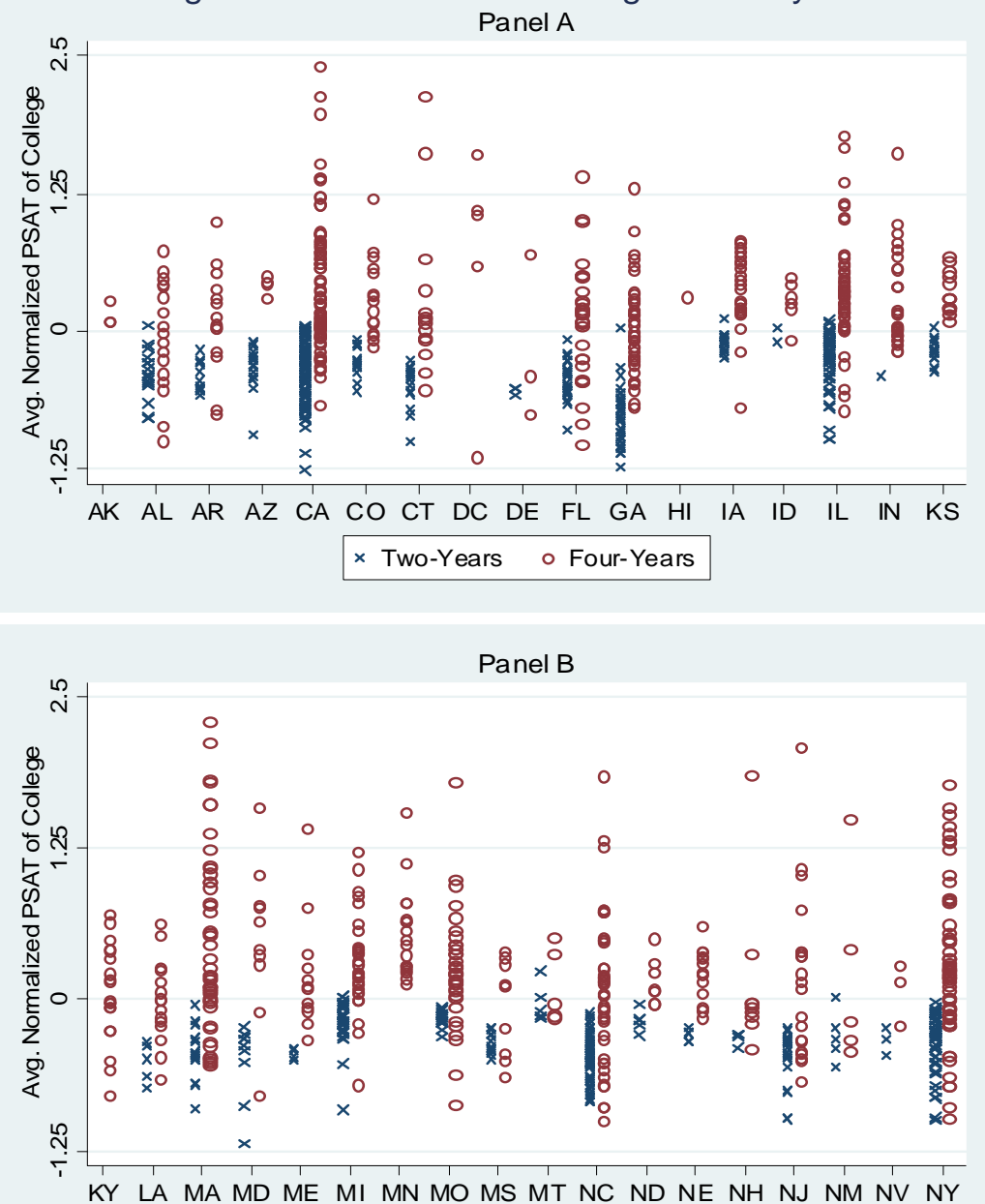

KY LA MA MD ME MI MN MO MS MT NC ND NE NH NJ NM NV NY

$$
\times \text { Two-Years ○ Four-Years }
$$

Panel C

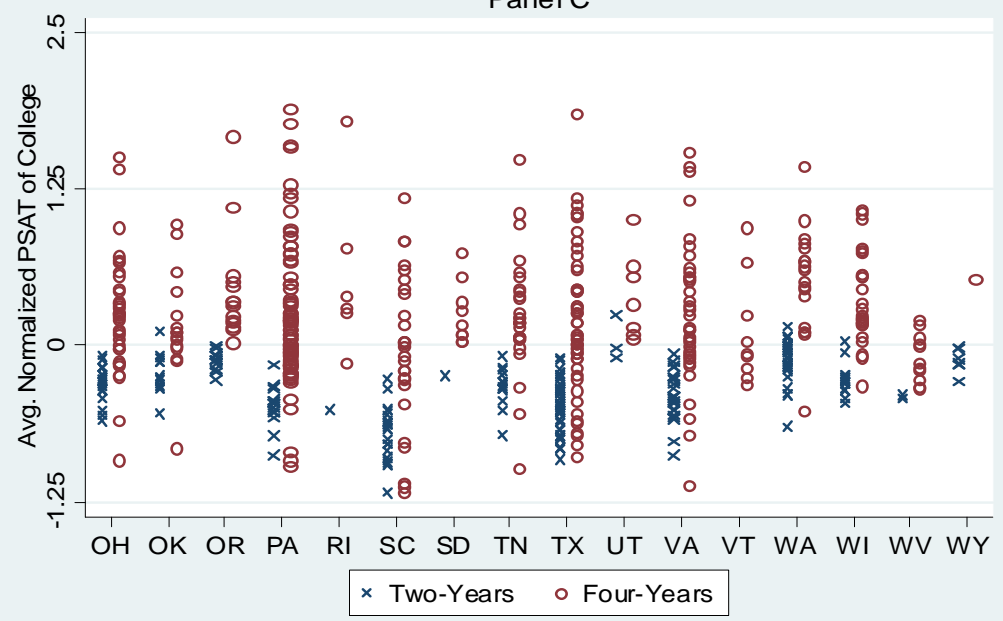

Notes: Each marker represents an individual college. Includes colleges with at least 50 PSAT test-takers combined across the 2004-2006 cohorts. 


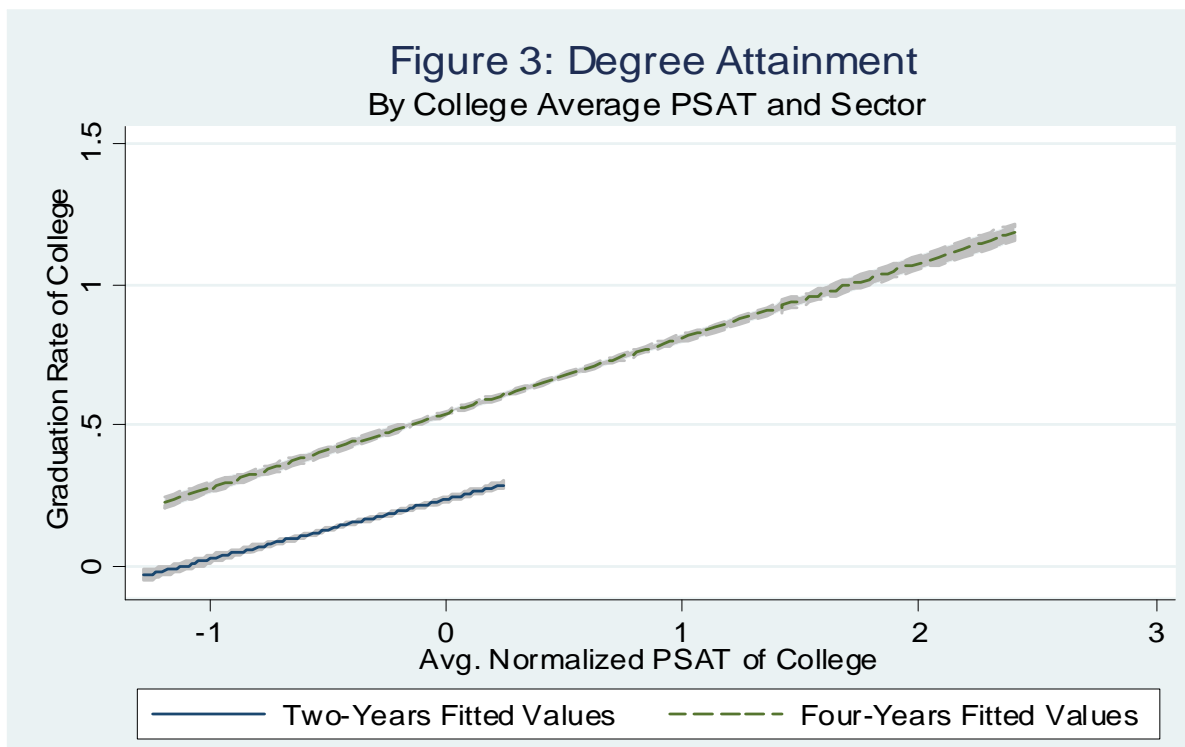

Notes: Uses linear regression model. Shaded regions are the $95 \%$ confidence intervals. 
Table 1 - Student Summary Statistics

\begin{tabular}{|c|c|c|c|c|c|c|c|c|}
\hline \multirow[b]{2}{*}{ Outcomes } & \multicolumn{4}{|c|}{ Two-Year Colleges (obs $=988,155)$} & \multicolumn{4}{|c|}{ Four-Year Colleges (obs $=2,375,471$ ) } \\
\hline & Mean & Std. Dev. & $\underline{\text { Min }}$ & $\underline{M a x}$ & Mean & Std. Dev. & $\underline{\text { Min }}$ & $\underline{M a x}$ \\
\hline Receive AA & 0.160 & 0.367 & 0 & 1 & 0.017 & 0.130 & 0 & 1 \\
\hline Attend 4-Year Ever & 0.373 & 0.484 & 0 & 1 & 1.000 & 0.000 & 1 & 1 \\
\hline Receive BA & 0.163 & 0.369 & 0 & 1 & 0.683 & 0.465 & 0 & 1 \\
\hline Receive Any Degree & 0.321 & 0.467 & 0 & 1 & 0.700 & 0.458 & 0 & 1 \\
\hline \multicolumn{9}{|l|}{ Variables of Primary Interest } \\
\hline Student PSAT & -0.409 & 0.793 & -2.558 & 3.211 & 0.434 & 0.886 & -2.558 & 3.211 \\
\hline Expenditure per Student (\$1000s) & 3.682 & 1.515 & 0.000 & 131.122 & 9.017 & 7.688 & 0.537 & 77.794 \\
\hline College Average PSAT & -0.428 & 0.257 & -1.414 & 0.297 & 0.427 & 0.541 & -1.544 & 2.493 \\
\hline \multicolumn{9}{|l|}{ College Controls } \\
\hline In-State Tuition (\$1000s) & 2.667 & 1.843 & 0.508 & 19.890 & 11.089 & 9.362 & 1.527 & 37.820 \\
\hline Out-of-State Tuition (\$1000s) & 5.931 & 2.298 & 0.600 & 19.890 & 17.602 & 6.682 & 2.640 & 37.820 \\
\hline College's Percent Part-Time Students & 0.583 & 0.128 & 0.000 & 0.908 & 0.208 & 0.127 & 0.000 & 0.953 \\
\hline College's Enrollment & 13,436 & 10,459 & 165 & 57,026 & 13,689 & 10,238 & 156 & 49,886 \\
\hline College's Percent of Students Under 25 & 0.592 & 0.133 & 0 & 1 & 0.818 & 0.199 & 0 & 1 \\
\hline Public & 0.990 & 0.098 & 0 & 1 & 0.680 & 0.467 & 0 & 1 \\
\hline \multicolumn{9}{|l|}{ Student Controls } \\
\hline Male & 0.450 & 0.498 & 0 & 1 & 0.433 & 0.496 & 0 & 1 \\
\hline White & 0.603 & 0.489 & 0 & 1 & 0.708 & 0.455 & 0 & 1 \\
\hline Black & 0.148 & 0.356 & 0 & 1 & 0.101 & 0.302 & 0 & 1 \\
\hline Hispanic & 0.148 & 0.355 & 0 & 1 & 0.075 & 0.263 & 0 & 1 \\
\hline Asian & 0.048 & 0.214 & 0 & 1 & 0.074 & 0.262 & 0 & 1 \\
\hline Other Race & 0.053 & 0.223 & 0 & 1 & 0.042 & 0.201 & 0 & 1 \\
\hline High School GPA & 2.991 & 0.630 & 0 & 4.3 & 3.487 & 0.541 & 0 & 4.3 \\
\hline Population in Zip Code & 26,756 & 20,610 & 0 & 113,916 & 25,618 & 19,595 & 0 & 113,916 \\
\hline Percent of Population with Bachelor's Degree & 23.767 & 14.423 & 0 & 100 & 30.603 & 17.511 & 0 & 100 \\
\hline County Unemployment Rate & 4.980 & 1.553 & 0 & 20.9 & 4.866 & 1.487 & 0 & 20.900 \\
\hline \multicolumn{9}{|l|}{ Sorting Controls } \\
\hline Closest 2-Year Distance (miles) & 13.01 & 43.28 & 0.00 & 2136.64 & 18.50 & 79.73 & 0.00 & 2136.64 \\
\hline Closest 4-Year Distance (miles) & 12.97 & 21.39 & 0.00 & 2136.64 & 11.02 & 18.80 & 0.00 & 2136.64 \\
\hline Count of 2-Years within 25 Miles & 3.842 & 4.510 & 0 & 24 & 3.914 & 4.459 & 0 & 24.000 \\
\hline Count of 4 -Years within 25 Miles & 7.341 & 11.116 & 0 & 63 & 8.794 & 12.634 & 0 & 63.000 \\
\hline Avg. PSAT of Closest 2-Year & -0.460 & 0.272 & -1.410 & 0.297 & -0.428 & 0.270 & -1.410 & 0.297 \\
\hline Expenditures per Student of Closest 2-Year (\$1000s) & 3.707 & 1.571 & 0 & 28.274 & 3.763 & 1.961 & 0 & 28.274 \\
\hline In-State Tuition of Closest 2-Year (\$1000s) & 2.635 & 1.889 & 0 & 39.33 & 2.907 & 2.286 & 0 & 39.330 \\
\hline Out-of-State Tuition of Closest 2-Year (\$1000s) & 5.814 & 2.444 & 0 & 39.33 & 6.024 & 2.868 & 0 & 39.330 \\
\hline Avg. PSAT of Closest 4-Year & 0.226 & 0.537 & -1.293 & 2.493 & 0.261 & 0.521 & -1.293 & 2.493 \\
\hline Expenditures per Student of Closest 4-Year (\$1000s) & 7.565 & 5.981 & 0 & 77.794 & 7.788 & 6.591 & 0 & 77.794 \\
\hline In-State Tuition of Closest 4-Year (\$1000s) & 13.850 & 9.062 & 0 & 37.82 & 13.893 & 9.148 & 0 & 37.820 \\
\hline Out-of-State Tuition of Closest 4-Year (\$1000s) & 17.378 & 6.322 & 0 & 37.82 & 17.438 & 6.484 & 0 & 37.820 \\
\hline
\end{tabular}

Notes: Includes PSAT test takers who attend colleges with at least 50 PSAT test-takers combined across the 2004-2006 cohorts. All measures using PSAT are standardized by the mean and standard deviation of all PSAT takers in the corresponding year. 


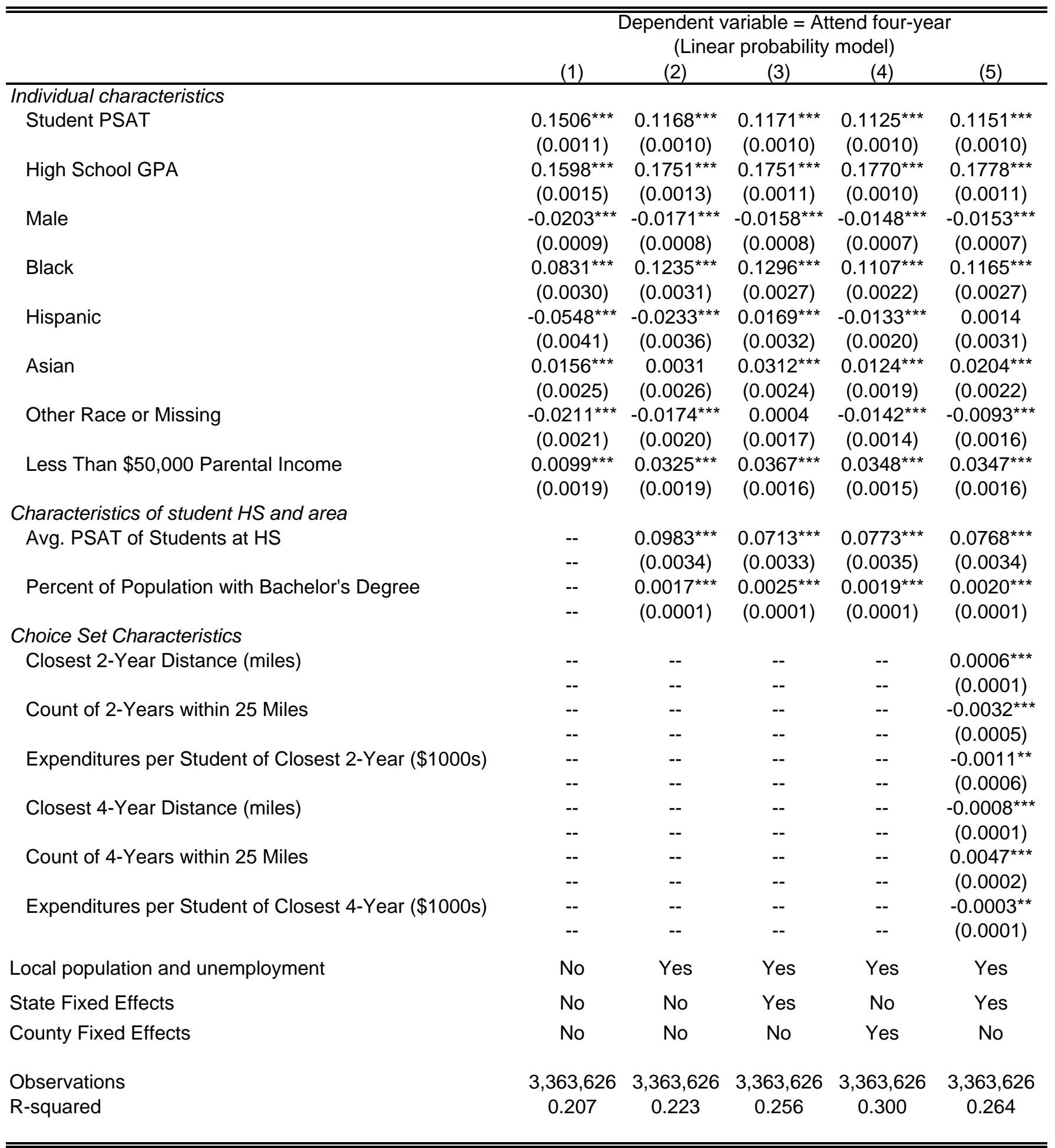

Notes: Includes PSAT test takers who attend colleges with at least 50 PSAT test-takers combined across the 20042006 cohorts. Standard errors in parentheses are clustered at the high school level. ${ }^{* * \star}$ means significant at $1 \%$ level, ${ }^{* *}$ at $5 \%$, and * at $10 \%$. All regressions control for year fixed effects. Local population and education are at the zip code level and unemployment is at the county level. All measures using PSAT are standardized by the mean and standard deviation of all PSAT takers in the corresponding year. 
Table 3 - Determinents of Peer Quality

\begin{tabular}{|c|c|c|c|c|c|c|c|c|}
\hline & \multicolumn{8}{|c|}{ Dependent variable $=$ Average normalized PSAT of college attended } \\
\hline & \multicolumn{4}{|c|}{ Two-year attendees } & \multicolumn{4}{|c|}{ Four-year attendees } \\
\hline & (1) & $(2)$ & $(3)$ & (4) & (5) & (6) & $(7)$ & $(8)$ \\
\hline \multicolumn{9}{|l|}{ Individual characteristics } \\
\hline Student PSAT & $\begin{array}{c}0.0648^{\star \star *} \\
(0.0012)\end{array}$ & $\begin{array}{c}0.0226^{\star * *} \\
(0.0008)\end{array}$ & $\begin{array}{c}0.0138^{\star * \star} \\
(0.0006)\end{array}$ & $\begin{array}{c}0.0139 * * * \\
(0.0005)\end{array}$ & $\begin{array}{c}0.3045^{\star \star *} \\
(0.0020)\end{array}$ & $\begin{array}{c}0.2376^{\star * *} \\
(0.0011)\end{array}$ & $\begin{array}{c}0.2324^{\star \star \star} \\
(0.0011)\end{array}$ & $\begin{array}{c}0.2317^{\star * \star} \\
(0.0011)\end{array}$ \\
\hline High School GPA & $\begin{array}{c}0.0190^{\star \star \star} \\
(0.0012)\end{array}$ & $\begin{array}{c}0.0249 * * * \\
(0.0011)\end{array}$ & $\begin{array}{c}0.0216 * \star * \\
(0.0007)\end{array}$ & $\begin{array}{c}0.0160 * \star \star \\
(0.0007)\end{array}$ & $\begin{array}{c}0.1637^{\star \star \star} \\
(0.0020)\end{array}$ & $\begin{array}{c}0.2138^{\star * *} \\
(0.0016)\end{array}$ & $\begin{array}{c}0.2230^{\star \star *} \\
(0.0015)\end{array}$ & $\begin{array}{c}0.2248^{\star \star *} \\
(0.0015)\end{array}$ \\
\hline Male & $\begin{array}{c}-0.0077^{\star \star \star} \\
(0.0008)\end{array}$ & $\begin{array}{c}-0.0026^{\star * \star} \\
(0.0008)\end{array}$ & $\begin{array}{c}0.0017^{\star \star \star} \\
(0.0006)\end{array}$ & $\begin{array}{c}0.0020 * \star \star \\
(0.0006)\end{array}$ & $\begin{array}{c}-0.0033^{\star \star *} \\
(0.0012)\end{array}$ & $\begin{array}{c}0.0051^{\star \star \star} \\
(0.0009)\end{array}$ & $\begin{array}{c}0.0076 * \star \star \\
(0.0009)\end{array}$ & $\begin{array}{c}0.0078^{\star * *} \\
(0.0009)\end{array}$ \\
\hline Black & $\begin{array}{c}-0.1778^{* * *} \\
(0.0044)\end{array}$ & $\begin{array}{c}-0.0736^{\star * *} \\
(0.0035)\end{array}$ & $\begin{array}{c}-0.0700 * * * \\
(0.0028)\end{array}$ & $\begin{array}{c}-0.0558^{* * *} \\
(0.0025)\end{array}$ & $\begin{array}{c}-0.1160 \text { *** } \\
(0.0040)\end{array}$ & $\begin{array}{c}-0.0342^{\star * *} \\
(0.0041)\end{array}$ & $\begin{array}{c}-0.0312^{\star * *} \\
(0.0039)\end{array}$ & $\begin{array}{c}-0.0363^{\star * *} \\
(0.0038)\end{array}$ \\
\hline Hispanic & $\begin{array}{c}-0.1419^{\star * *} \\
(0.0066)\end{array}$ & $\begin{array}{c}-0.0548^{* \star *} \\
(0.0048)\end{array}$ & $\begin{array}{c}-0.0951 \text { *** } \\
(0.0034)\end{array}$ & $\begin{array}{c}-0.0783^{\star \star *} \\
(0.0035)\end{array}$ & $\begin{array}{l}-0.0039 \\
(0.0053)\end{array}$ & $\begin{array}{c}0.0617^{* \star * *} \\
(0.0043)\end{array}$ & $\begin{array}{c}0.0446^{\star * *} \\
(0.0037)\end{array}$ & $\begin{array}{c}0.0420^{\star * *} \\
(0.0037)\end{array}$ \\
\hline Asian & $\begin{array}{c}-0.0175^{\star * *} \\
(0.0044)\end{array}$ & $\begin{array}{c}0.0022 \\
(0.0041)\end{array}$ & $\begin{array}{c}-0.0385^{\star * *} \\
(0.0031)\end{array}$ & $\begin{array}{c}-0.0187^{* * *} \\
(0.0026)\end{array}$ & $\begin{array}{c}0.1645^{\star * *} \\
(0.0030)\end{array}$ & $\begin{array}{c}0.1425^{\star * *} \\
(0.0028)\end{array}$ & $\begin{array}{c}0.1186^{\star \star *} \\
(0.0026)\end{array}$ & $\begin{array}{c}0.1113^{* * *} \\
(0.0027)\end{array}$ \\
\hline Other Race or Missing & $\begin{array}{c}-0.0528^{\star \star *} \\
(0.0027)\end{array}$ & $\begin{array}{c}-0.0140^{* * *} \\
(0.0022)\end{array}$ & $\begin{array}{c}-0.0377^{\star \star *} \\
(0.0017)\end{array}$ & $\begin{array}{c}-0.0249 * \star \star \\
(0.0015)\end{array}$ & $\begin{array}{c}0.0488^{\star * *} \\
(0.0024)\end{array}$ & $\begin{array}{c}0.0527^{* \star *} \\
(0.0020)\end{array}$ & $\begin{array}{c}0.0405^{\star * *} \\
(0.0019)\end{array}$ & $\begin{array}{c}0.0378^{\star \star \star *} \\
(0.0019)\end{array}$ \\
\hline \multicolumn{9}{|l|}{ Characteristics of student HS and area } \\
\hline Avg PSAT of Students at HS & $\begin{array}{l}-- \\
--\end{array}$ & $\begin{array}{c}0.2427^{\star \star \star} \\
(0.0049)\end{array}$ & $\begin{array}{c}0.1333^{\star \star \star} \\
(0.0041)\end{array}$ & $\begin{array}{c}0.1138^{\star \star \star} \\
(0.0039)\end{array}$ & $\begin{array}{l}-- \\
--\end{array}$ & $\begin{array}{c}0.1642^{\star \star \star} \\
(0.0040)\end{array}$ & $\begin{array}{c}0.1560^{\star \star *} \\
(0.0044)\end{array}$ & $\begin{array}{c}0.1566^{\star \star \star} \\
(0.0044)\end{array}$ \\
\hline Percent of Population with Bachelor's Degree & $\begin{array}{l}-- \\
-\end{array}$ & $\begin{array}{c}-0.0012^{\star \star \star} \\
(0.0001)\end{array}$ & $\begin{array}{c}-0.0006^{\star \star \star} \\
(0.0001)\end{array}$ & $\begin{array}{c}0.0001 \\
(0.0001)\end{array}$ & $\begin{array}{l}-- \\
--\end{array}$ & $\begin{array}{c}0.0042^{\star \star \star} \\
(0.0001)\end{array}$ & $\begin{array}{c}0.0043^{\star \star \star} \\
(0.0001)\end{array}$ & $\begin{array}{c}0.0041^{\star \star *} \\
(0.0001)\end{array}$ \\
\hline \multicolumn{9}{|l|}{ Choice Set Characteristics } \\
\hline Closest 2-Year Distance (miles) & $\begin{array}{l}-- \\
--\end{array}$ & $\begin{array}{l}-- \\
--\end{array}$ & $\begin{array}{l}-- \\
--\end{array}$ & $\begin{array}{c}-0.0003^{\star \star \star} \\
(0.0000)\end{array}$ & $\begin{array}{l}-- \\
--\end{array}$ & $\begin{array}{l}-- \\
--\end{array}$ & $\begin{array}{l}-- \\
--\end{array}$ & $\begin{array}{c}-0.0001^{\star * \star} \\
(0.0000)\end{array}$ \\
\hline Count of 2-Years within 25 Miles & $\begin{array}{l}-- \\
--\end{array}$ & $\begin{array}{l}-- \\
--\end{array}$ & $\begin{array}{l}-- \\
--\end{array}$ & $\begin{array}{c}-0.0033^{* * *} \\
(0.0006)\end{array}$ & $\begin{array}{l}-- \\
--\end{array}$ & $\begin{array}{l}-- \\
--\end{array}$ & $\begin{array}{l}-- \\
--\end{array}$ & $\begin{array}{c}0.0049 * * * \\
(0.0005)\end{array}$ \\
\hline Expenditures per Student of Closest 2-Year (\$1000s) & $\begin{array}{l}-- \\
--\end{array}$ & $\begin{array}{l}-- \\
--\end{array}$ & $\begin{array}{l}-- \\
--\end{array}$ & $\begin{array}{l}-0.0004 \\
(0.0007)\end{array}$ & $\begin{array}{l}-- \\
--\end{array}$ & $\begin{array}{l}-- \\
--\end{array}$ & $\begin{array}{l}-- \\
--\end{array}$ & $\begin{array}{c}0.0002 \\
(0.0005)\end{array}$ \\
\hline Closest 4-Year Distance (miles) & $\begin{array}{l}-- \\
--\end{array}$ & $\begin{array}{l}-- \\
--\end{array}$ & $\begin{array}{l}-- \\
--\end{array}$ & $\begin{array}{c}0.0005^{\star \star \star \star} \\
(0.0001)\end{array}$ & $\begin{array}{l}-- \\
--\end{array}$ & $\begin{array}{l}-- \\
--\end{array}$ & $\begin{array}{l}-- \\
--\end{array}$ & $\begin{array}{c}0.0003^{\star * *} \\
(0.0000)\end{array}$ \\
\hline Count of 4 -Years within 25 Miles & $\begin{array}{l}-- \\
--\end{array}$ & $\begin{array}{l}-- \\
--\end{array}$ & $\begin{array}{l}-- \\
--\end{array}$ & $\begin{array}{c}-0.0042^{\star * *} \\
(0.0002)\end{array}$ & $\begin{array}{l}-- \\
--\end{array}$ & $\begin{array}{l}-- \\
--\end{array}$ & $\begin{array}{l}-- \\
--\end{array}$ & $\begin{array}{l}-0.0002 \\
(0.0002)\end{array}$ \\
\hline Expenditures per Student of Closest 4-Year (\$1000s) & $\begin{array}{l}-- \\
-\end{array}$ & $\begin{array}{l}-- \\
-\end{array}$ & $\begin{array}{l}-- \\
--\end{array}$ & $\begin{array}{c}0.0001 \\
(0.0003)\end{array}$ & $\begin{array}{l}-- \\
--\end{array}$ & $\begin{array}{l}-- \\
--\end{array}$ & $\begin{array}{l}-- \\
-\end{array}$ & $\begin{array}{c}0.0011^{\star \star \star} \\
(0.0002)\end{array}$ \\
\hline Local population and unemployment & No & Yes & Yes & Yes & No & Yes & Yes & Yes \\
\hline State Fixed Effects & No & No & Yes & Yes & No & No & Yes & Yes \\
\hline Observations & 988,155 & 988,155 & 988,155 & 988,155 & $2,375,471$ & $2,375,471$ & $2,375,471$ & $2,375,471$ \\
\hline R-squared & 0.183 & 0.333 & 0.502 & 0.532 & 0.408 & 0.454 & 0.463 & 0.464 \\
\hline
\end{tabular}


Table 4 - Effect of Peer Ability and Sector on Bachelor's Degree Attainment

Dependent variable $=$ Attain bachelor's degree within six years of high school

\begin{tabular}{|c|c|c|c|c|c|c|c|}
\hline & $(1)$ & $(2)$ & $(3)$ & $(4)$ & $(5)$ & $(6)$ & $(7)$ \\
\hline Four-Year College & - & $\begin{array}{c}0.5151^{\star \star \star} \\
(0.0105)\end{array}$ & $\begin{array}{c}0.2959 \star \star \star \\
(0.0112)\end{array}$ & $\begin{array}{c}0.3018^{\star \star \star} \\
(0.0111)\end{array}$ & $\begin{array}{c}0.3252^{\star \star *} \\
(0.0085)\end{array}$ & $\begin{array}{c}0.3296 * \star \star \\
(0.0080)\end{array}$ & $\begin{array}{c}0.3150 * \star \star \\
(0.0081)\end{array}$ \\
\hline Average PSAT of College & $\begin{array}{c}0.3982^{\star \star \star} \\
(0.0099)\end{array}$ & - & $\begin{array}{c}0.2594^{\star \star \star} \\
(0.0110)\end{array}$ & $\begin{array}{c}0.1766^{\star \star \star} \\
(0.0112)\end{array}$ & $\begin{array}{l}0.0274^{\star \star} \\
(0.0126)\end{array}$ & $\begin{array}{c}0.0142 \\
(0.0131)\end{array}$ & $\begin{array}{c}0.0649 * \star \star \\
(0.0139)\end{array}$ \\
\hline x Four-Year College & - & - & - & - & $\begin{array}{c}0.1142^{\star \star \star} \\
(0.0164)\end{array}$ & $\begin{array}{c}0.1562^{\star \star \star} \\
(0.0182)\end{array}$ & $\begin{array}{c}0.1089 * * * \\
(0.0176)\end{array}$ \\
\hline Student PSAT & - & - & - & $\begin{array}{c}0.0560 * \star * \\
(0.0015)\end{array}$ & $\begin{array}{c}0.0234^{\star \star *} \\
(0.0017)\end{array}$ & $\begin{array}{l}0.0067^{* \star} \\
(0.0029)\end{array}$ & $\begin{array}{c}0.0473^{\star * *} \\
(0.0027)\end{array}$ \\
\hline x Four-Year College & - & - & - & - & $\begin{array}{c}-0.0060 * \star \star \\
(0.0023)\end{array}$ & $\begin{array}{c}0.0315^{\star * *} \\
(0.0048)\end{array}$ & $\begin{array}{l}-0.0067^{*} \\
(0.0035)\end{array}$ \\
\hline Average PSAT of College $x$ Student PSAT & - & - & - & - & - & $\begin{array}{c}-0.0455^{\star \star \star} \\
(0.0057)\end{array}$ & $\begin{array}{c}0.0514^{* * *} \\
(0.0056)\end{array}$ \\
\hline Average PSAT of College $x$ Student PSAT x Four-Year College & - & - & - & - & - & - & $\begin{array}{c}-0.1024^{\star \star \star} \\
(0.0083)\end{array}$ \\
\hline Average PSAT of Student High School & - & - & - & $\begin{array}{c}0.0694^{\star \star *} \\
(0.0025)\end{array}$ & $\begin{array}{l}0.0671^{\star \star \star} \\
(0.0021)\end{array}$ & $\begin{array}{c}0.0662^{\star \star \star} \\
(0.0020)\end{array}$ & $\begin{array}{c}0.0667^{\star \star \star} \\
(0.0020)\end{array}$ \\
\hline Student Controls & No & No & No & No & Yes & Yes & Yes \\
\hline $\begin{array}{l}\text { Observations } \\
\text { R-squared }\end{array}$ & $\begin{array}{c}3,363,626 \\
0.252\end{array}$ & $\begin{array}{c}3,363,626 \\
0.236\end{array}$ & $\begin{array}{c}3,363,626 \\
0.294\end{array}$ & $\begin{array}{c}3,363,626 \\
0.306\end{array}$ & $\begin{array}{c}3,363,626 \\
0.335\end{array}$ & $\begin{array}{c}3,363,626 \\
0.337\end{array}$ & $\begin{array}{c}3,363,626 \\
0.338\end{array}$ \\
\hline
\end{tabular}

Note: Includes PSAT test takers who attend colleges with at least 50 PSAT test-takers combined across the 2004-2006 cohorts. Standard errors in parentheses are clustered at the college level. ${ }^{* \star \star}$ means significant at $1 \%$ level, ${ }^{* \star}$ at $5 \%$, and ${ }^{*}$ at $10 \%$. All regressions control for year and state fixed effects. College controls include in-state and out-of-state tuition, percent of students who are part-time, number of students, and percent of students who are under 25 years old. Student controls include sex, race/ethnicity, parental low-income status, high school GPA, home zip code's population and bachelor's degree attainment rate, and home county's unemployment rate. All measures using PSAT are standardized by the mean and standard deviation of all PSAT takers in the corresponding year. 
Table 5 - Effect of Peer Ability and Sector on Bachelor's Degree Attainment - Robustness

Dependent variable $=$ Attain bachelor's degree within six years of high school

\begin{tabular}{|c|c|c|c|c|c|c|}
\hline & $(1)$ & $(2)$ & (3) & (4) & $(5)$ & (6) \\
\hline Four-Year College & $\begin{array}{c}0.3150^{\star * *} \\
(0.0081)\end{array}$ & $\begin{array}{c}0.3005^{\star \star \star} \\
(0.0108)\end{array}$ & $\begin{array}{c}0.2128^{\star * \star} \\
(0.0139)\end{array}$ & $\begin{array}{l}0.2066^{\star \star \star} \\
(0.0136)\end{array}$ & $\begin{array}{l}0.2015^{\star \star *} \\
(0.0168)\end{array}$ & $\begin{array}{l}0.2196 * \star \star \\
(0.0183)\end{array}$ \\
\hline Average PSAT of College & $\begin{array}{c}0.0649 * \star \star \\
(0.0139)\end{array}$ & $\begin{array}{c}0.0661 * \star \star \\
(0.0138)\end{array}$ & $\begin{array}{c}0.0546^{\star \star \star} \\
(0.0118)\end{array}$ & $\begin{array}{l}0.0528^{\star \star \star} \\
(0.0116)\end{array}$ & $\begin{array}{l}0.0551^{\star \star \star} \\
(0.0136)\end{array}$ & $\begin{array}{l}0.0360^{*} \\
(0.0199)\end{array}$ \\
\hline x Four-Year College & $\begin{array}{c}0.1089 * * \star \\
(0.0176)\end{array}$ & $\begin{array}{c}0.1105^{\star \star \star} \\
(0.0186)\end{array}$ & $\begin{array}{c}0.0474^{\star \star \star} \\
(0.0177)\end{array}$ & $\begin{array}{l}0.0484^{\star \star \star} \\
(0.0173)\end{array}$ & $\begin{array}{l}0.0537 * \star \star \\
(0.0207)\end{array}$ & $\begin{array}{l}0.0779 * \star * \\
(0.0243)\end{array}$ \\
\hline Student PSAT & $\begin{array}{c}0.0473^{\star \star \star} \\
(0.0027)\end{array}$ & $\begin{array}{c}0.0473^{\star \star \star} \\
(0.0027)\end{array}$ & $\begin{array}{c}0.0474^{\star \star \star} \\
(0.0029)\end{array}$ & $\begin{array}{l}0.0418^{\star \star \star} \\
(0.0028)\end{array}$ & $\begin{array}{l}0.0473^{\star \star \star} \\
(0.0035)\end{array}$ & $\begin{array}{l}0.0495^{\star \star \star} \\
(0.0077)\end{array}$ \\
\hline x Four-Year College & $\begin{array}{l}-0.0067^{*} \\
(0.0035)\end{array}$ & $\begin{array}{c}-0.0074^{\star \star} \\
(0.0037)\end{array}$ & $\begin{array}{l}-0.0074^{\star} \\
(0.0038)\end{array}$ & $\begin{array}{l}-0.0070^{*} \\
(0.0037)\end{array}$ & $\begin{array}{l}-0.0144 \star \star \star \\
(0.0044)\end{array}$ & $\begin{array}{l}-0.0192^{\star *} \\
(0.0081)\end{array}$ \\
\hline Average PSAT of College $\times$ Student PSAT & $\begin{array}{c}0.0514^{\star * *} \\
(0.0056)\end{array}$ & $\begin{array}{c}0.0513^{\star * *} \\
(0.0057)\end{array}$ & $\begin{array}{c}0.0508^{\star * *} \\
(0.0064)\end{array}$ & $\begin{array}{l}0.0507^{\star \star \star} \\
(0.0063)\end{array}$ & $\begin{array}{l}0.0506^{\star \star *} \\
(0.0075)\end{array}$ & $\begin{array}{l}0.0501^{* * *} \\
(0.0143)\end{array}$ \\
\hline Average PSAT of College $x$ Student PSAT $x$ Four-Year College & $\begin{array}{c}-0.1024^{\star \star *} \\
(0.0083)\end{array}$ & $\begin{array}{c}-0.1006^{\star \star \star} \\
(0.0089)\end{array}$ & $\begin{array}{c}-0.0995^{\star \star \star} \\
(0.0087)\end{array}$ & $\begin{array}{l}-0.0993^{\star \star \star} \\
(0.0085)\end{array}$ & $\begin{array}{l}-0.0981^{\star \star \star} \\
(0.0100)\end{array}$ & $\begin{array}{l}-0.0928^{\star \star \star} \\
(0.0160)\end{array}$ \\
\hline Average PSAT of Student High School & $\begin{array}{c}0.0667^{\star \star \star} \\
(0.0020)\end{array}$ & $\begin{array}{c}0.0667^{\star \star \star} \\
(0.0020)\end{array}$ & $\begin{array}{c}0.0643^{\star \star \star} \\
(0.0018)\end{array}$ & $\begin{array}{l}0.0627^{\star \star \star} \\
(0.0018)\end{array}$ & $\begin{array}{l}0.0572^{\star \star \star} \\
(0.0020)\end{array}$ & $\begin{array}{l}0.0476^{\star \star \star} \\
(0.0023)\end{array}$ \\
\hline Expenditures per Student & - & $\begin{array}{c}-0.0043^{\star \star *} \\
(0.0015)\end{array}$ & $\begin{array}{c}-0.0054^{\star \star *} \\
(0.0013)\end{array}$ & $\begin{array}{l}-0.0054^{\star \star *} \\
(0.0013)\end{array}$ & $\begin{array}{l}-0.0055^{\star * *} \\
(0.0016)\end{array}$ & $\begin{array}{l}-0.0029 \\
(0.0023)\end{array}$ \\
\hline x Four-Year College & - & $\begin{array}{l}0.0039 * * \\
(0.0017)\end{array}$ & $\begin{array}{c}0.0044^{\star * *} \\
(0.0015)\end{array}$ & $\begin{array}{l}0.0045^{\star \star \star} \\
(0.0014)\end{array}$ & $\begin{array}{l}0.0048^{\star \star *} \\
(0.0017)\end{array}$ & $\begin{array}{l}0.0019 \\
(0.0024)\end{array}$ \\
\hline Sent SAT Score to at least one Four-Year College & - & - & - & $\begin{array}{l}0.0597^{\star \star \star} \\
(0.0017)\end{array}$ & $\begin{array}{l}0.0688^{\star \star \star} \\
(0.0018)\end{array}$ & $\begin{array}{l}0.0718^{\star \star \star} \\
(0.0026)\end{array}$ \\
\hline College Controls & No & No & Yes & Yes & Yes & Yes \\
\hline Only SAT States & No & No & No & No & Yes & No \\
\hline Only PSAT States & No & No & No & No & No & Yes \\
\hline
\end{tabular}

Observations

$3,363,626 \quad 3,363,626 \quad 3,363,626 \quad 3,363,626 \quad 2,272,896 \quad 1,066,469$ R-squared

$\begin{array}{llllll}0.338 & 0.338 & 0.342 & 0.345 & 0.360 & 0.367\end{array}$

Note: Includes PSAT test takers who attend colleges with at least 50 PSAT test-takers combined across the 2004-2006 cohorts. Standard errors in parentheses are clustered at the college level. ${ }^{\star \star *}$ means significant at $1 \%$ level, ${ }^{*}$ at $5 \%$, and ${ }^{*}$ at $10 \%$. All regressions control for year and state fixed effects and student controls (include sex, race/ethnicity, parental low-income status, high school GPA, home zip code's population and bachelor's degree attainment rate, and home county's unemployment rate). College controls include in-state and out-of-state tuition, percent of students who are part-time, number of students, and percent of students who are under 25 years old. SAT States are the 22 states in which more students take the SAT than the ACT. PSAT States are the 9 states in which at least $75 \%$ of high school graduates take the PSAT. All measures using PSAT are standardized by the mean and standard deviation of all PSAT takers in the corresponding year. 


\begin{tabular}{|c|c|c|c|c|c|c|c|c|c|c|}
\hline & Bache & Ior's Degree & within & Associ & iate's Degre & within & An & y Degree wi & ithin & $\begin{array}{c}\text { Ever Attend } \\
\text { 4-year }\end{array}$ \\
\hline & $\frac{4 \text { Years }}{(1)}$ & $\frac{6 \text { Years }}{(2)}$ & $\frac{8 \text { Years }}{(3)}$ & $\frac{4 \text { Years }}{(4)}$ & $\frac{6 \text { Years }}{(5)}$ & $\frac{8 \text { Years }}{(6)}$ & $\frac{4 \text { Years }}{(7)}$ & $\frac{6 \text { Years }}{(8)}$ & $\frac{8 \text { Years }}{(9)}$ & $(10)$ \\
\hline Four-Year College & $\begin{array}{c}0.0620 * * * \\
(0.0140)\end{array}$ & $\begin{array}{c}0.2066^{\star * *} \\
(0.0136)\end{array}$ & $\begin{array}{c}0.2155^{\star * \star} \\
(0.0225)\end{array}$ & $\begin{array}{c}-0.1009^{* * *} \\
(0.0076)\end{array}$ & $\begin{array}{c}-0.1331^{* \star *} \\
(0.0094)\end{array}$ & $\begin{array}{c}-0.1405^{\star \star \star} \\
(0.0099)\end{array}$ & $\begin{array}{c}-0.0375^{\star \star \star} \\
(0.0143)\end{array}$ & $\begin{array}{c}0.0762^{\star * *} \\
(0.0146)\end{array}$ & $\begin{array}{c}0.0777^{\star * *} \\
(0.0225)\end{array}$ & $\begin{array}{l}-- \\
--\end{array}$ \\
\hline Average PSAT of College & $\begin{array}{c}-0.0126 \\
(0.0121)\end{array}$ & $\begin{array}{c}0.0528^{\star \star \star} \\
(0.0116)\end{array}$ & $\begin{array}{c}0.0709^{\star \star *} \\
(0.0146)\end{array}$ & $\begin{array}{c}-0.0079 \\
(0.0093)\end{array}$ & $\begin{array}{c}-0.0289^{\star \star} \\
(0.0123)\end{array}$ & $\begin{array}{c}-0.0235 \\
(0.0143)\end{array}$ & $\begin{array}{c}-0.0215 \\
(0.0155)\end{array}$ & $\begin{array}{c}0.0222 \\
(0.0171)\end{array}$ & $\begin{array}{l}0.0462^{\star *} \\
(0.0200)\end{array}$ & $\begin{array}{c}0.0522^{\star \star *} \\
(0.0143)\end{array}$ \\
\hline x Four-Year College & $\begin{array}{c}0.1037^{\star \star \star} \\
(0.0167)\end{array}$ & $\begin{array}{c}0.0484^{\star * *} \\
(0.0173)\end{array}$ & $\begin{array}{c}0.0340 \\
(0.0289)\end{array}$ & $\begin{array}{l}-0.0036 \\
(0.0089)\end{array}$ & $\begin{array}{c}0.0122 \\
(0.0116)\end{array}$ & $\begin{array}{c}0.0046 \\
(0.0118)\end{array}$ & $\begin{array}{c}0.1013^{\star \star \star} \\
(0.0187)\end{array}$ & $\begin{array}{c}0.0626^{\star \star *} \\
(0.0208)\end{array}$ & $\begin{array}{c}0.0399 \\
(0.0312)\end{array}$ & $\begin{array}{l}-- \\
--\end{array}$ \\
\hline Student PSAT & $\begin{array}{c}0.0104^{\star * *} \\
(0.0028)\end{array}$ & $\begin{array}{c}0.0418^{\star * *} \\
(0.0028)\end{array}$ & $\begin{array}{c}0.0398^{\star * *} \\
(0.0034)\end{array}$ & $\begin{array}{c}0.0037 \\
(0.0024)\end{array}$ & $\begin{array}{c}0.0004 \\
(0.0030)\end{array}$ & $\begin{array}{l}-0.0010 \\
(0.0032)\end{array}$ & $\begin{array}{c}0.0132^{\star * *} \\
(0.0030)\end{array}$ & $\begin{array}{c}0.0409 * * * \\
(0.0037)\end{array}$ & $\begin{array}{c}0.0379 * \star * \\
(0.0044)\end{array}$ & $\begin{array}{c}0.0598^{* * *} \\
(0.0031)\end{array}$ \\
\hline x Four-Year College & $\begin{array}{c}0.0430 * \star \star \\
(0.0039)\end{array}$ & $\begin{array}{l}-0.0070^{*} \\
(0.0037)\end{array}$ & $\begin{array}{c}-0.0066 \\
(0.0064)\end{array}$ & $\begin{array}{c}-0.0114 \text { *** } \\
(0.0024)\end{array}$ & $\begin{array}{c}-0.0121^{\star * \star} \\
(0.0030)\end{array}$ & $\begin{array}{c}-0.0102^{\star \star *} \\
(0.0033)\end{array}$ & $\begin{array}{c}0.0327^{\star \star \star} \\
(0.0041)\end{array}$ & $\begin{array}{c}-0.0175^{\star \star \star} \\
(0.0043)\end{array}$ & $\begin{array}{c}-0.0155^{\star *} \\
(0.0069)\end{array}$ & $\begin{array}{l}-- \\
--\end{array}$ \\
\hline Average PSAT of College $\times$ Student PSAT & $\begin{array}{c}0.0363^{\star * *} \\
(0.0057)\end{array}$ & $\begin{array}{c}0.0507^{\star \star *} \\
(0.0063)\end{array}$ & $\begin{array}{c}0.0424^{\star * *} \\
(0.0071)\end{array}$ & $\begin{array}{c}-0.0116^{\star *} \\
(0.0058)\end{array}$ & $\begin{array}{c}-0.0203^{\star * *} \\
(0.0070)\end{array}$ & $\begin{array}{c}-0.0218^{\star \star \star} \\
(0.0075)\end{array}$ & $\begin{array}{c}0.0237^{\star * *} \\
(0.0061)\end{array}$ & $\begin{array}{c}0.0292^{\star * *} \\
(0.0083)\end{array}$ & $\begin{array}{l}0.0200 * * \\
(0.0096)\end{array}$ & $\begin{array}{l}0.0166^{\star *} \\
(0.0066)\end{array}$ \\
\hline Average PSAT of College $x$ Student PSAT $x$ Four-Year College & $\begin{array}{c}-0.0349^{\star * \star} \\
(0.0083)\end{array}$ & $\begin{array}{c}-0.0993^{* * *} \\
(0.0085)\end{array}$ & $\begin{array}{c}-0.1023^{\star \star \star} \\
(0.0156)\end{array}$ & $\begin{array}{l}0.0129^{\star *} \\
(0.0060)\end{array}$ & $\begin{array}{c}0.0226^{\star \star *} \\
(0.0073)\end{array}$ & $\begin{array}{c}0.0240 * \star * \\
(0.0077)\end{array}$ & $\begin{array}{c}-0.0211^{\text {** }} \\
(0.0085)\end{array}$ & $\begin{array}{c}-0.0757^{\star * *} \\
(0.0103)\end{array}$ & $\begin{array}{c}-0.0778^{\star \star \star} \\
(0.0169)\end{array}$ & $\begin{array}{l}-- \\
--\end{array}$ \\
\hline Average PSAT of Student High School & $\begin{array}{c}0.0300^{\star * *} \\
(0.0018)\end{array}$ & $\begin{array}{c}0.0627^{\star \star \star *} \\
(0.0018)\end{array}$ & $\begin{array}{c}0.0597^{\star \star *} \\
(0.0025)\end{array}$ & $\begin{array}{c}0.0063^{\star * \star} \\
(0.0006)\end{array}$ & $\begin{array}{c}0.0071^{\star \star *} \\
(0.0008)\end{array}$ & $\begin{array}{c}0.0059^{\star \star *} \\
(0.0009)\end{array}$ & $\begin{array}{c}0.0363^{\star \star *} \\
(0.0017)\end{array}$ & $\begin{array}{c}0.0696^{\star \star *} \\
(0.0018)\end{array}$ & $\begin{array}{c}0.0653^{\star * \star} \\
(0.0026)\end{array}$ & $\begin{array}{c}0.1003^{\star \star *} \\
(0.0029)\end{array}$ \\
\hline Expenditures per Student & $\begin{array}{c}-0.0053^{\star * \star} \\
(0.0014)\end{array}$ & $\begin{array}{c}-0.0054^{\star * *} \\
(0.0013)\end{array}$ & $\begin{array}{c}-0.0052^{\star \star \star} \\
(0.0016)\end{array}$ & $\begin{array}{c}0.0047^{\star \star \star} \\
(0.0013)\end{array}$ & $\begin{array}{c}0.0048^{\star * \star} \\
(0.0016)\end{array}$ & $\begin{array}{c}0.0050^{\star \star \star} \\
(0.0017)\end{array}$ & $\begin{array}{l}-0.0005 \\
(0.0016)\end{array}$ & $\begin{array}{c}-0.0005 \\
(0.0016)\end{array}$ & $\begin{array}{c}-0.0001 \\
(0.0014)\end{array}$ & $\begin{array}{l}-0.0027 \\
(0.0020)\end{array}$ \\
\hline x Four-Year College & $\begin{array}{l}0.0032^{\star *} \\
(0.0016)\end{array}$ & $\begin{array}{c}0.0045^{\star \star \star} \\
(0.0014)\end{array}$ & $\begin{array}{c}0.0035 \\
(0.0023)\end{array}$ & $\begin{array}{c}-0.0045^{\star \star *} \\
(0.0013)\end{array}$ & $\begin{array}{c}-0.0046 \text { *** } \\
(0.0016)\end{array}$ & $\begin{array}{c}-0.0048^{\star \star \star} \\
(0.0017)\end{array}$ & $\begin{array}{l}-0.0014 \\
(0.0018)\end{array}$ & $\begin{array}{c}-0.0002 \\
(0.0017)\end{array}$ & $\begin{array}{c}-0.0014 \\
(0.0021)\end{array}$ & $\begin{array}{l}-- \\
--\end{array}$ \\
\hline Sent SAT Score to at least one Four-Year College & $\begin{array}{c}0.0302^{\star \star *} \\
(0.0016)\end{array}$ & $\begin{array}{c}0.0597^{\star \star \star} \\
(0.0017)\end{array}$ & $\begin{array}{c}0.0551^{\star * *} \\
(0.0024)\end{array}$ & $\begin{array}{c}0.0035^{\star \star *} \\
(0.0006)\end{array}$ & $\begin{array}{c}0.0039 * * * \\
(0.0008)\end{array}$ & $\begin{array}{c}0.0037^{\star * *} \\
(0.0009)\end{array}$ & $\begin{array}{c}0.0337^{\star * *} \\
(0.0016)\end{array}$ & $\begin{array}{c}0.0636^{\star * *} \\
(0.0019)\end{array}$ & $\begin{array}{c}0.0589 * * * \\
(0.0025)\end{array}$ & $\begin{array}{c}0.1219 * * * \\
(0.0025)\end{array}$ \\
\hline Only 2004 Cohort & No & No & Yes & No & No & Yes & No & No & Yes & No \\
\hline Only Two-Year Colleges & No & No & No & No & No & No & No & No & No & Yes \\
\hline Observations & $3,363,626$ & $3,363,626$ & $1,074,266$ & $3,363,626$ & $3,363,626$ & $1,074,266$ & $3,363,626$ & $3,363,626$ & $1,074,266$ & 988,155 \\
\hline R-squared & 0.294 & 0.345 & 0.310 & 0.068 & 0.090 & 0.091 & 0.227 & 0.251 & 0.222 & 0.108 \\
\hline
\end{tabular}

Note: Includes PSAT test takers who attend colleges with at least 50 PSAT test-takers combined across the 2004-2006 cohorts. Standard errors in parentheses are clustered at the college

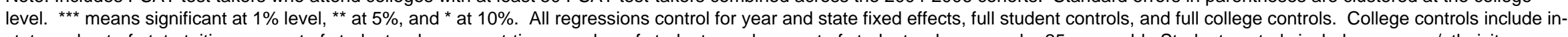
state and out-of-state tuition, percent of students who are part-time, number of students, and percent of students who are under 25 years old. Student controls include sex, race/ethnicity, parental low-income status, high school GPA, home zip code's population and bachelor's degree attainment rate, and home county's unemployment rate. All measures using PSAT are standardized by the mean and standard deviation of all PSAT takers in the corresponding year. 
Table A1. Comparison between Analysis Sample and Two National Samples

\begin{tabular}{|c|c|c|c|c|c|c|}
\hline & \multicolumn{3}{|c|}{ 4-year students } & \multicolumn{3}{|c|}{ 2-year students } \\
\hline & & & $2003 / 4$ & & & $2003 / 4$ \\
\hline & & & Beginning & & & Beginning \\
\hline & & 2004 High & Postsecondary & & 2004 High & Postsecondary \\
\hline & $\begin{array}{l}\text { Analysis } \\
\text { sample }\end{array}$ & $\begin{array}{l}\text { School Seniors } \\
\text { (ELS sample) }\end{array}$ & $\begin{array}{c}\text { Students } \\
\text { (BPS sample) }\end{array}$ & Analysis sample & $\begin{array}{l}\text { School Seniors } \\
\text { (ELS sample) }\end{array}$ & $\begin{array}{c}\text { Students } \\
\text { (BPS sample) }\end{array}$ \\
\hline$\%$ of sample & $70.62 \%$ & $61.20 \%$ & $48.20 \%$ & $29.38 \%$ & $38.80 \%$ & $51.80 \%$ \\
\hline \multicolumn{7}{|l|}{ Outcomes } \\
\hline Receive BA (within 8 years) & 0.669 & 0.640 & & 0.170 & 0.185 & \\
\hline Receive BA (within 6 years) & 0.663 & & 0.613 & 0.165 & & 0.116 \\
\hline Ever attend 4-year & 1.000 & & 1.000 & 0.373 & 0.375 & 0.266 \\
\hline \multicolumn{7}{|l|}{ Institutional characteristics } \\
\hline Public & 0.680 & 0.701 & 0.657 & 0.990 & 0.991 & 0.979 \\
\hline \multicolumn{7}{|l|}{ Student characteristics } \\
\hline Male & 0.433 & 0.463 & 0.445 & 0.450 & 0.466 & 0.434 \\
\hline White & 0.708 & 0.695 & 0.699 & 0.603 & 0.585 & 0.604 \\
\hline Black & 0.101 & 0.116 & 0.098 & 0.148 & 0.132 & 0.140 \\
\hline Hispanic & 0.075 & 0.088 & 0.097 & 0.148 & 0.204 & 0.159 \\
\hline Asian & 0.074 & 0.057 & 0.062 & 0.048 & 0.037 & 0.048 \\
\hline Other race & 0.042 & 0.044 & 0.044 & 0.053 & 0.042 & 0.048 \\
\hline HS GPA & 3.487 & 3.417 & 3.568 & 2.991 & 2.845 & 3.103 \\
\hline Took SAT & 0.741 & 0.646 & 0.692 & 0.508 & 0.305 & 0.405 \\
\hline No delayed PSE enrollment & 0.919 & 0.920 & 0.876 & 0.753 & 0.677 & 0.522 \\
\hline
\end{tabular}

Notes: National samples tabulated using NCES PowerStats Version 1.0. ELS Sample drawn from 11,656 students who were high school seniors in 2004 and who responded to the third follow-up of the Education Longitudinal Study of 2002 (weighted by F3QWT). BPS sample drawn from 16,100 students who were beginning postsecondary students in 2003/2004 who responded to the 2009 follow-up of the Beginning Postseconday Study 2004/2009 (weighted by WTB000). Both samples restricted to students whose first PSE was a public 2-year, a public or non-profit 4-year. Initial sector and outcomes for ELS sample are taken 8 years after high school graduation. Average HS GPA for ELS and BPS is calculated by taking the weighted sum across 0.50 categories. "Took SAT" for ELS sample includes 6-7\% of students that took either the SAT or ACT, but were not sure which one. "Took SAT" in BPS only for students < = 24 years old. "No delayed PSE enrollment" is defined as enrollment within the first six months after HS graduation for the ELS sample and within the first academic year after high school graduation for the BPS sample. BA attainment rates for analysis sample are presented for the 2004 cohort only in order to have a consistent sample for 6-year and 8-year BA attainment rates. 


\section{Appendix Table A2 - College Summary Statistics}

\begin{tabular}{|c|c|c|c|c|c|c|c|c|}
\hline & \multicolumn{4}{|c|}{ Two-Year Colleges } & \multicolumn{4}{|c|}{ Four-Year Colleges (obs = 3,165) } \\
\hline & \multicolumn{2}{|c|}{ In-Sample $(n=2,133)$} & \multicolumn{2}{|c|}{ Out-of-Sample $(n=562)$} & \multicolumn{2}{|c|}{ In-Sample $(n=3,165)$} & \multicolumn{2}{|c|}{ Out-of-Sample $(n=1,081)$} \\
\hline & Mean & Std. Dev. & Mean & Std. Dev. & Mean & Std. Dev. & Mean & Std. Dev. \\
\hline \multicolumn{9}{|l|}{ Outcomes (calculated) } \\
\hline Receive AA & 0.182 & 0.088 & -- & -- & 0.020 & 0.016 & -- & -- \\
\hline Attend 4-Year Ever & 0.369 & 0.129 & -- & -- & 1.000 & 0.000 & -- & -- \\
\hline Receive BA & 0.159 & 0.093 & -- & -- & 0.611 & 0.202 & -- & -- \\
\hline Receive Any Degree & 0.338 & 0.125 & -- & -- & 0.630 & 0.196 & -- & -- \\
\hline \multicolumn{9}{|l|}{ College Variables } \\
\hline College Average PSAT (calculated) & -0.373 & 0.266 & -- & -- & 0.246 & 0.549 & -- & -- \\
\hline Expenditure per Student (\$1000s) & 4.032 & 3.301 & 3.821 & 2.638 & 7.981 & 6.851 & 8.795 & 13.077 \\
\hline In-State Tuition (\$1000s) & 2.823 & 2.101 & 3.545 & 4.032 & 14.002 & 9.157 & 15.345 & 8.077 \\
\hline Out-of-State Tuition (\$1000s) & 5.974 & 2.748 & 6.382 & 3.663 & 17.176 & 6.773 & 16.979 & 6.686 \\
\hline College's Percent Part-Time Students & 0.564 & 0.143 & 0.548 & 0.181 & 0.229 & 0.155 & 0.251 & 0.203 \\
\hline College's Enrollment & 6,809 & 6,602 & 6,285 & 6,658 & 5,765 & 6,694 & 3,693 & 5,186 \\
\hline College's Percent of Students Under 25 & 0.572 & 0.151 & 0.482 & 0.239 & 0.760 & 0.225 & 0.589 & 0.349 \\
\hline Public & 0.977 & 0.148 & 0.899 & 0.302 & 0.411 & 0.492 & 0.271 & 0.445 \\
\hline Population & 20,427 & 18,183 & 24,000 & 19,243 & 17,179 & 17,360 & 19,030 & 17,084 \\
\hline Percent of Population with Bachelor's Degree & 20.1 & 13.9 & 22.5 & 14.7 & 24.3 & 20.8 & 29.3 & 21.5 \\
\hline Local Unemployment Rate & 4.9 & 2.1 & 5.0 & 2.2 & 3.8 & 2.5 & 4.3 & 2.1 \\
\hline \multicolumn{9}{|l|}{ Sorting Controls } \\
\hline Closest 2-Year Distance (miles) & 28.568 & 23.335 & 25.521 & 23.124 & 20.278 & 75.426 & 28.185 & 131.126 \\
\hline Closest 4-Year Distance (miles) & 18.934 & 23.142 & 18.035 & 21.788 & 15.576 & 27.527 & 12.224 & 19.238 \\
\hline Count of 2 -Years within 25 Miles & 2.432 & 4.170 & 3.107 & 4.631 & 3.231 & 4.329 & 3.404 & 3.981 \\
\hline Count of 4 -Years within 25 Miles & 5.353 & 10.041 & 5.705 & 9.768 & 8.041 & 13.875 & 9.784 & 15.262 \\
\hline
\end{tabular}

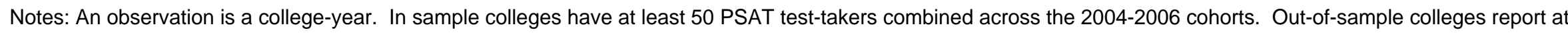
least these data. Outcome variables and average PSAT are calculated only from observed PSAT takers in that cohort. All for profit colleges are excluded. Local area characteristics (population, percent of population with Bachelor's degree, unemployment rate) are calculated for the county in which the college is located. 
Appendix Table A3 - Correlates of Average PSAT of College

Observation at College-Year Leve

Dependent Variable = Average Normalized PSAT of College

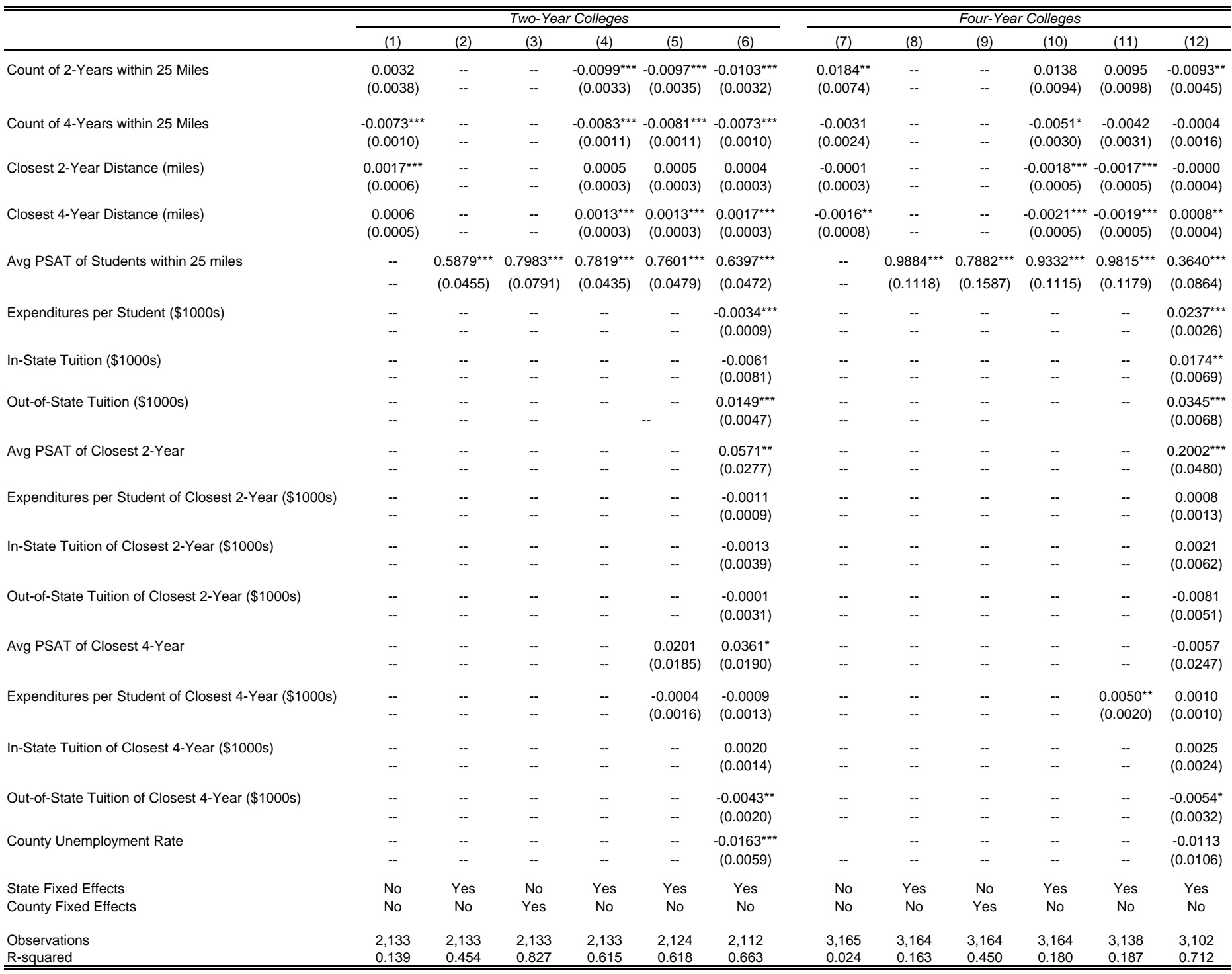

Note: Includes colleges with at least 50 PSAT test-takers combined across the 2004-2006 cohorts. Standard errors in parentheses are clustered at the college level. ${ }^{* \star}$ means significant at $1 \%$ level, ${ }^{\star}$ at $5 \%$, and * at $10 \%$. All regressions control for year fixed effects. Columns 8 and 16 also control for percent of students who are part-time, number of students, and percent of students who are under 25 years old, zip code's population and bachelor's degree attainment rate. Variables with missing values set to zero and an indicator included in regression. All measures using PSAT are 


\begin{tabular}{|c|c|c|c|}
\hline & \multirow{3}{*}{$\begin{array}{c}\begin{array}{c}\text { Attend four-year } \\
\text { (Linear prob. } \\
\text { model) }\end{array} \\
\text { All students } \\
(6)\end{array}$} & \multicolumn{2}{|c|}{ Average PSAT of college attended } \\
\hline & & 2-year students & 4-year students \\
\hline & & $(6)$ & $(12)$ \\
\hline \multicolumn{4}{|l|}{ Individual characteristics } \\
\hline Student PSAT & $\begin{array}{c}0.1244^{\star \star *} \\
(0.0026)\end{array}$ & $\begin{array}{c}0.0224^{\star \star *} \\
(0.0028)\end{array}$ & $\begin{array}{c}0.1952^{\star \star *} \\
(0.0029)\end{array}$ \\
\hline High School GPA & $\begin{array}{c}0.1782^{\star \star *} \\
(0.0011)\end{array}$ & $\begin{array}{c}0.0157^{\star \star \star} \\
(0.0007)\end{array}$ & $\begin{array}{c}0.2225^{\star * *} \\
(0.0015)\end{array}$ \\
\hline Male & $\begin{array}{c}-0.0154^{\star \star *} \\
(0.0007)\end{array}$ & $\begin{array}{c}0.0020^{\star \star \star} \\
(0.0006)\end{array}$ & $\begin{array}{c}0.0080^{\star * *} \\
(0.0009)\end{array}$ \\
\hline Black & $\begin{array}{c}0.1168^{\star \star *} \\
(0.0027)\end{array}$ & $\begin{array}{c}-0.0560^{* * *} \\
(0.0025)\end{array}$ & $\begin{array}{c}-0.0401^{* \star *} \\
(0.0038)\end{array}$ \\
\hline Hispanic & $\begin{array}{c}0.0030 \\
(0.0031)\end{array}$ & $\begin{array}{c}-0.0774^{* * *} \\
(0.0035)\end{array}$ & $\begin{array}{c}0.0413^{\star \star *} \\
(0.0038)\end{array}$ \\
\hline Asian & $\begin{array}{c}0.0208^{\star \star *} \\
(0.0021)\end{array}$ & $\begin{array}{c}-0.0187^{\star \star * *} \\
(0.0025)\end{array}$ & $\begin{array}{l}0.1042^{\star \star *} \\
(0.0030)\end{array}$ \\
\hline Other Race or Missing & $\begin{array}{c}-0.0098^{* * *} \\
(0.0016)\end{array}$ & $\begin{array}{c}-0.0251^{\star * *} \\
(0.0015)\end{array}$ & $\begin{array}{c}0.0372^{\star \star *} \\
(0.0019)\end{array}$ \\
\hline Less Than $\$ 50,000$ Parental Income & $\begin{array}{c}0.0338^{\star \star *} \\
(0.0016)\end{array}$ & $\begin{array}{c}-0.0041^{* * *} \\
(0.0011)\end{array}$ & $\begin{array}{c}-0.0245^{\star \star * *} \\
(0.0015)\end{array}$ \\
\hline \multicolumn{4}{|l|}{ Characteristics of student HS and area } \\
\hline Avg PSAT of Students at HS & $\begin{array}{c}0.0797^{\star \star \star} \\
(0.0033)\end{array}$ & $\begin{array}{l}0.1141^{\star \star \star} \\
(0.0039)\end{array}$ & $\begin{array}{c}0.1447^{\star \star \star} \\
(0.0045)\end{array}$ \\
\hline Percent of Population with Bachelor's Degree & $\begin{array}{c}0.0020^{\star \star \star} \\
(0.0001)\end{array}$ & $\begin{array}{c}0.0001 \\
(0.0001)\end{array}$ & $\begin{array}{l}0.0040^{* * *} \\
(0.0001)\end{array}$ \\
\hline \multicolumn{4}{|l|}{ Choice Set Characteristics } \\
\hline Closest 2-Year Distance (miles) & $\begin{array}{c}0.0006^{\star \star \star} \\
(0.0001)\end{array}$ & $\begin{array}{c}-0.0003^{\star * *} \\
(0.0000)\end{array}$ & $\begin{array}{c}-0.0002^{* \star *} \\
(0.0000)\end{array}$ \\
\hline above $\times$ Student PSAT & $\begin{array}{c}-0.0001^{\star \star \star} \\
(0.0000)\end{array}$ & $\begin{array}{c}-0.0000 \\
(0.0000)\end{array}$ & $\begin{array}{l}-0.0000 \\
(0.0000)\end{array}$ \\
\hline Count of 2-Years within 25 Miles & $\begin{array}{c}-0.0034^{\star \star \star} \\
(0.0005)\end{array}$ & $\begin{array}{c}-0.0024^{\star \star *} \\
(0.0006)\end{array}$ & $\begin{array}{c}0.0043^{* * *} \\
(0.0005)\end{array}$ \\
\hline above $\times$ Student PSAT & $\begin{array}{l}0.0015^{\star \star \star} \\
(0.0002)\end{array}$ & $\begin{array}{l}0.0015^{\star \star \star} \\
(0.0003)\end{array}$ & $\begin{array}{l}0.0013^{\star \star \star} \\
(0.0003)\end{array}$ \\
\hline Expenditures per Student of Closest 2-Year (\$1000s) & $\begin{array}{l}-0.0010 \\
(0.0006)\end{array}$ & $\begin{array}{l}-0.0011 \\
(0.0007)\end{array}$ & $\begin{array}{l}-0.0007 \\
(0.0005)\end{array}$ \\
\hline above $\times$ Student PSAT & $\begin{array}{l}-0.0002 \\
(0.0005)\end{array}$ & $\begin{array}{c}-0.0018^{\star \star \star *} \\
(0.0005)\end{array}$ & $\begin{array}{l}0.0017^{\star \star \star} \\
(0.0005)\end{array}$ \\
\hline Closest 4-Year Distance (miles) & $\begin{array}{c}-0.0008^{\star \star *} \\
(0.0001)\end{array}$ & $\begin{array}{l}0.0006^{\star \star \star} \\
(0.0001)\end{array}$ & $\begin{array}{c}0.0002^{\star \star \star} \\
(0.0001)\end{array}$ \\
\hline above $x$ Student PSAT & $\begin{array}{l}0.0001^{\star *} \\
(0.0000)\end{array}$ & $\begin{array}{l}0.0001^{\star *} \\
(0.0000)\end{array}$ & $\begin{array}{c}-0.0003^{\star \star \star \star} \\
(0.0001)\end{array}$ \\
\hline Count of 4-Years within 25 Miles & $\begin{array}{c}0.0048^{\star * *} \\
(0.0002)\end{array}$ & $\begin{array}{c}-0.0048^{\star * *} \\
(0.0002)\end{array}$ & $\begin{array}{c}-0.0011^{\star \star \star} \\
(0.0002)\end{array}$ \\
\hline above $\times$ Student PSAT & $\begin{array}{c}-0.0012^{\star \star \star} \\
(0.0001)\end{array}$ & $\begin{array}{c}-0.0009 * \star \star \\
(0.0001)\end{array}$ & $\begin{array}{l}0.0025^{\star \star \star} \\
(0.0001)\end{array}$ \\
\hline Expenditures per Student of Closest 4-Year (\$1000s) & $\begin{array}{l}-0.0003^{*} \\
(0.0001)\end{array}$ & $\begin{array}{l}-0.0000 \\
(0.0003)\end{array}$ & $\begin{array}{l}0.0007^{* \star *} \\
(0.0002)\end{array}$ \\
\hline above $\times$ Student PSAT & $\begin{array}{c}-0.0004^{\star * \star} \\
(0.0001)\end{array}$ & $\begin{array}{l}-0.0003 \\
(0.0002)\end{array}$ & $\begin{array}{l}0.0009^{\star \star *} \\
(0.0002)\end{array}$ \\
\hline Local population, education, and unemployment & Yes & Yes & Yes \\
\hline Observations & $3,363,626$ & 988,155 & $2,375,471$ \\
\hline R-squared & 0.265 & 0.533 & 0.469 \\
\hline
\end{tabular}


Table A5 - Effect of Peer Ability and Sector on Bachelor's Degree Attainment

Alternative Measures of College PSAT

Dependent variable $=$ Attain bachelor's degree within six years of high school

\begin{tabular}{|c|c|c|c|c|}
\hline & Avg. PSAT & 25th Percentile PSAT & Median PSAT & 75th Percentile PSAT \\
\hline Four-Year College & $\begin{array}{c}0.3252^{\star \star *} \\
(0.0085)\end{array}$ & $\begin{array}{c}0.3791^{\star \star *} \\
(0.0123)\end{array}$ & $\begin{array}{c}0.3280^{\star \star *} \\
(0.0084)\end{array}$ & $\begin{array}{c}0.2787^{\star * *} \\
(0.0115)\end{array}$ \\
\hline Average PSAT of College & $\begin{array}{l}0.0274^{\star *} \\
(0.0126)\end{array}$ & $\begin{array}{l}0.0266^{\star *} \\
(0.0127)\end{array}$ & $\begin{array}{l}0.0260^{\star *} \\
(0.0120)\end{array}$ & $\begin{array}{l}0.0278^{\star *} \\
(0.0118)\end{array}$ \\
\hline x Four-Year College & $\begin{array}{c}0.1142^{\star \star \star} \\
(0.0164)\end{array}$ & $\begin{array}{c}0.1158^{\star \star \star} \\
(0.0165)\end{array}$ & $\begin{array}{c}0.1101^{\star \star \star} \\
(0.0159)\end{array}$ & $\begin{array}{c}0.1051^{\star \star \star} \\
(0.0159)\end{array}$ \\
\hline x Four-Year College & $\begin{array}{c}-0.0060^{\star * *} \\
(0.0023)\end{array}$ & $\begin{array}{c}-0.0074^{\star * *} \\
(0.0024)\end{array}$ & $\begin{array}{c}-0.0054^{* *} \\
(0.0023)\end{array}$ & $\begin{array}{l}-0.0030 \\
(0.0023)\end{array}$ \\
\hline Average PSAT of Student High School & $\begin{array}{c}0.0671^{\star \star \star} \\
(0.0021)\end{array}$ & $\begin{array}{c}0.0664^{\star \star \star} \\
(0.0021)\end{array}$ & $\begin{array}{c}0.0672^{\star \star \star} \\
(0.0021)\end{array}$ & $\begin{array}{c}0.0681^{\star \star \star} \\
(0.0022)\end{array}$ \\
\hline
\end{tabular}

Note: Includes PSAT test takers who attend colleges with at least 50 PSAT test-takers combined across the 2004-2006 cohorts. Standard errors in parentheses are clustered at the college level. ${ }^{\star \star \star}$ means significant at $1 \%$ level, ${ }^{* \star}$ at $5 \%$, and ${ }^{*}$ at $10 \%$. All regressions control for year and state fixed effects. College controls include in-state and out-of-state tuition, percent of students who are part-time, number of students, and percent of students who are under 25 years old. Student controls include sex, race/ethnicity, parental low-income status, high school GPA, home zip code's population and bachelor's degree attainment rate, and home county's unemployment rate. All measures using PSAT are standardized by the mean and standard deviation of all PSAT takers in the corresponding year. 
Figure A1. Correlation between average PSAT and SAT

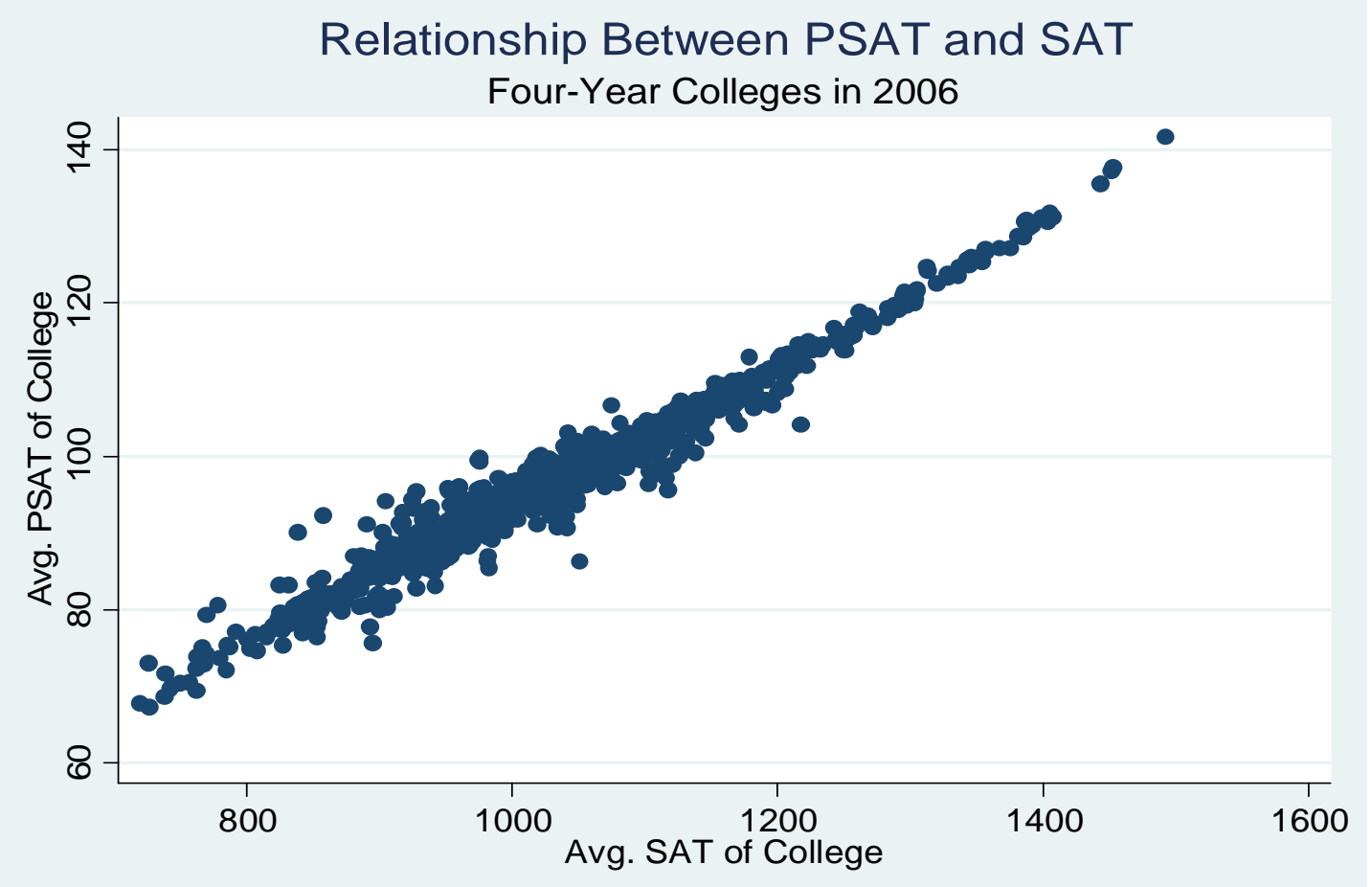



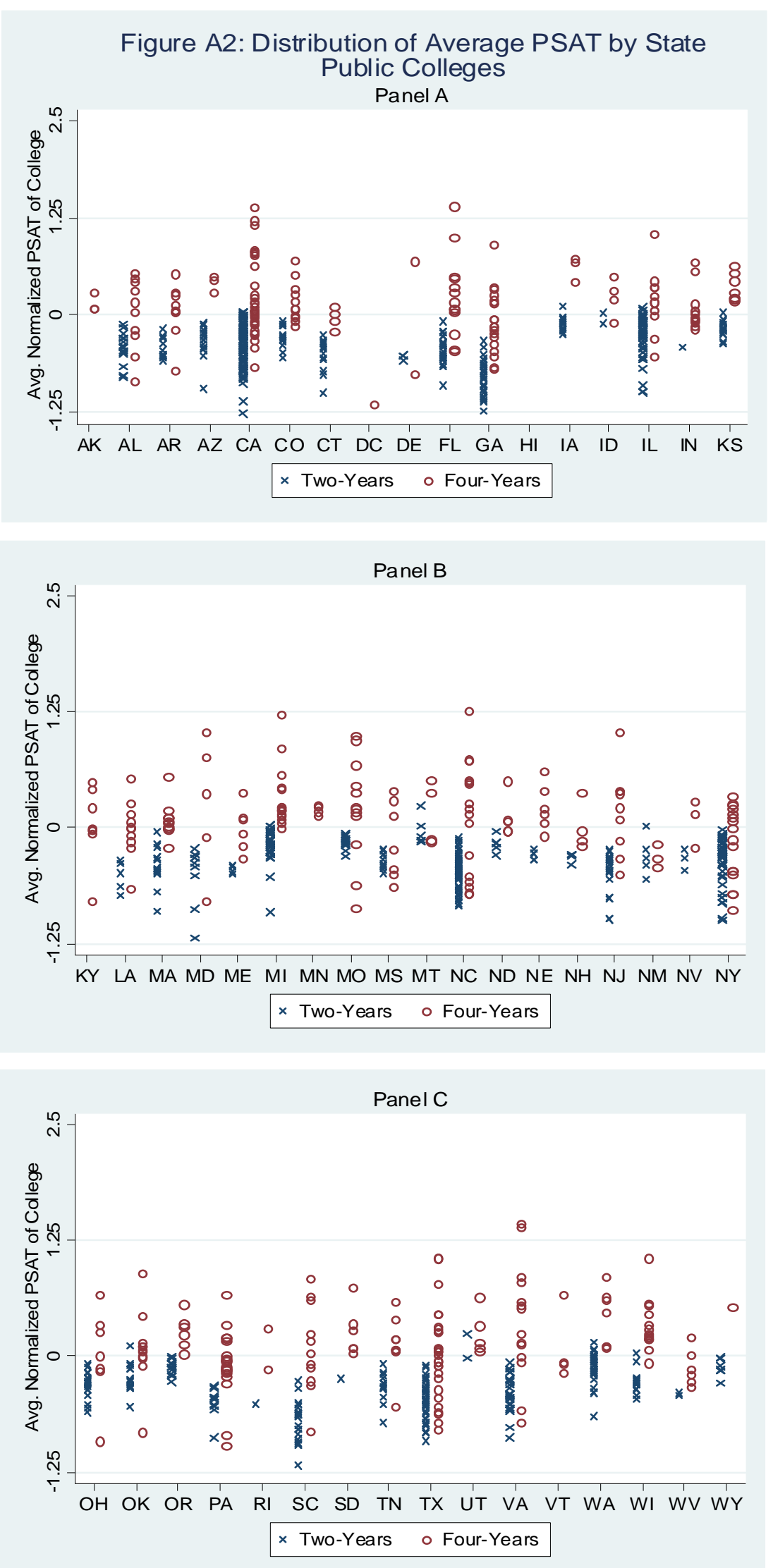

Notes: Each marker represents an individual college. Includes public colleges with at least 50 PSAT test-takers combined across the 2004-2006 cohorts. 